\title{
DAMPAK ASIMETRIS TERHADAP OUTPUT DALAM SEBUAH SERIKAT MONETER DENGAN PENDEKATAN META-ANALYSIS
}

\author{
MHA. Ridhwan'
}

\begin{abstract}
The regional impact of the monetary policy has been a crucial issue especially on its distributional impact. Using Meta-Analysis, this paper run a quantitative survey on previous studies to explain the asymmetric impact of national policy on economic growth across region. Based on selected criteria we have similar researches on sample data; mainly they used VAR method.

Our model estimation shows the significant and importance of capital intensity degree, the financial depth and several macroeconomic indicators in explaining the different result across region and period of these studies. In general our finding confirms the robustness of their result.
\end{abstract}

Keywords: Monetary union, output, Meta-Analysis

JEL Classification. E52, R11, C83

1 The author is an economist of Bank Indonesia, and currently being a PhD candidate at the VU University Amsterdam and Tinbergen Institute, Netherlands. Email: mha_ridwan@bi.go.id. With the usual disclaimers I thank Piet Rietveld, Peter Nijkamp, Henri L.F. de Groot for thorough supervisions, and Patricia Stekelenburg for excellent research assistance. Ame Trandem has generously edited this manuscript. The earlier version of this paper has been presented in NARSC Meetings in Brooklyn, NY-USA, November 2008; and ERSA Conference, Lodz-Poland, July 2009. 


\section{PENDAHULUAN}

"Meskipun banyak ahli makroekonomi yang akan mengakui adanya sedikit ketidakpastian tentang hal ini, namun profesi ini secara keseluruhan tidak memiliki jawaban jelas terhadap pertanyaan tentang besar dan sifat dari dampak kebijakan moneter terhadap aktivitas agregat" (Sims, 1992).

Dampak kebijakan moneter terhadap ekonomi riil telah menjadi bahan perdebatan dalam makroekonomi. Pencarian akan 'apa yang ada dalam kotak hitam'2 menimbulkan pertanyaan apakah mengubah nilai tukar akan berdampak pada variabel ekonomi riil, ${ }^{3}$ dan jika ya, seberapa kuat dampaknya.

Perdebatan tentang transmisi moneter (monetary transmission) bahkan lebih nyata jika melihat dimensi regional, ${ }^{4}$ karena kebijakan moneter pada dasarnya menyasar target nasional, sementara berbagai daerah (region) dalam uni moneter memiliki struktur dan karakteristik yang berbeda-beda. Karenanya, mereka mungkin memberikan respon yang asimetris terhadap impuls kebijakan moneter yang seragam. Akibatnya, kebijakan ini akan memiliki implikasi distribusional yang berbeda di daerah tersebut, aktivitas ekonomi di daerah inti (core region) mungkin akan terdorong oleh kebijakan moneter, sementara daerah pinggiran (periphery) menjadi lebih tertekan. ${ }^{5}$

Dampak distribusional dari kebijakan moneter bersama sampai saat ini masih menarik perhatian dan menimbulkan kekhawatiran dari para pembuat kebijakan dan akademisi, terutama setelah munculnya Uni Moneter Eropa (European Monetary Union - EMU) pada tahun 1999. Meskipun ada berbagai harapan baik dari unifikasi ini, namun juga timbul ketakutan bahwa hal ini akan menyebabkan divergensi ekonomi di negara-negara yang tergabung di dalamnya. ${ }^{6}$

Untuk mengurai masalah ini, berbagai studi telah berusaha mengkaji dampak regional dari kebijakan moneter. Sebagai contoh, Carlino dan De Fina (CD) (1998, 1999), dan Owyang

2 Bernanke dan Gertler (1995) memperkenalkan istilah "kotak hitan" untuk menunjukkan adanya puzzle dalam hasil studi transmisi moneter

3 Jalur nilai tukar (exchange-rate channel) adalah cara konvensional dimana kebijakan moneter diasumsikan dijalankan dalam ekonomi yang besar, cukup tertutup dengan sistem keuangan yang sudah berkembang. Jalur transmisi moneter yang lain yang biasanya ditemukan dalam literatur kebijakan moneter adalah pinjaman bank, nilai tukar, ekspektasi, dan aset-harga (lihat, misalnya, Mishkin, 1995, 1996)

4 Pendekatan neoklasik tradisional telah mengesampingkan peran uang dalam pembangunan ekonomi terutama dalam jangka panjang (dikenal dengan netralitas moneter jangka panjang).

5 Ridhwan et al. (2008) telah mensurvei kaitan antara kebijakan moneter dengan pembangunan regional, dan mereka membahas implikasi dari kebijakan bersama bagi daerah inti (core) dan pinggiran (peripheral).

6 Area EMU sangat mengacu pada teori Optimum Currency Areas (OCA). Terori OCA pada dasarnya memaparkan prasyarat bagi negara-negara yang berpartisipasi agar bisa memiliki dampak simetris terhadap kebijakan makroekonomi bersama. Bahkan jika beberapa diantaranya mengalami gonjangan yang asimetris, namun ketersediaan beberapa mekanisme penyesuaian akan melindungi beberapa potensi ketidakseimbangan dalam negara itu, antara lain melalui pasar faktor (factor market) yang fleksibel, yakni mobilitas faktor yang tinggi dan harga yang bisa disesuaikan; serta penstabilan fiskal secara otomatis. 
dan Wall (OW) (2004) mengkaji AS; sementara Ramaswamy dan Kloek (1998) dan Clements et al (2001) mempelajari negara-negara Eropa. Secara umum, hasil temuan mereka memperlihatkan adanya dampak output yang berbeda dalam merespon gonjangan kebijakan bersama (common policy shock).

Studi lain terutama tentang negara-negara Eropa berkesimpulan bahwa dampak output di area Euro sangatlah mirip (lihat, misalnya, Peersman, 2004). Gerlach dan Smets (1995) dan Kieler dan Saaranheimo (1998) berkesimpulan bahwa hanya ada sedikit atau bahkan tidak ada perbedaan dalam transmisi moneter di negara-negara tersebut. Temuan yang saling bertentangan ini cenderung mengindikasikan bahwa masih belum ada kesepakatan tentang apakah kebijakan "satu untuk semua" bisa menimbulkan dampak asimetris di seluruh daerah. ${ }^{7}$ Pada beberapa kasus, besaran (size) dan lintasan waktu (time-path) dari dampak output diketahui sangat berbeda-beda dari satu studi ke studi lain. ${ }^{8}$

Dengan melihat kondisi ini, studi yang kami lakukan mencoba untuk menelaah kembali dan membahas masalah yang tak terselesaikan dengan memaparkan survei kuantitatif dengan menggunakan metode yang disebut meta-analisis. Florax et al. (2002) berpandangan bahwa metode ini menggunakan pendekatan yang lebih sistematis dalam menganalisa sumber variasi (kuantitatif) dalam hasil penelitian yang diperoleh sebelumnya, dan karenanya bisa membantu dalam analisa kebijakan ekonomi terapan seperti dalam studi transmisi moneter ini.

De Grauwe dan Storti (2004) mengkaji dampak kebijakan moneter terhadap variabel riil di berbagai negara, dan menemukan bahwa perbedaan metodologi dalam berbagai studi sangat mempengaruhi variasi dampak moneter. Dengan menggunakan teknik yang sama, Pitzel dan Uuskula (2005), dengan hanya menggunakan sampel kecil, berkesimpulan bahwa transmisi moneter di negara-negara Eropa sangat dipengaruhi oleh kedalaman dan struktur finansial. ${ }^{9}$

7 Istilah asimetri dalam studi moneter bisa lebih terkait dengan dampak output yang berbeda dari kebijakan moneter yang ketat dan mudah. Cover (1992) memaparkan bukti awal tentang dampak asimetri bahwa gonjangan uang beredar (money-supply shock) yang positif tidak berdampak pada output, sementara gonjangan uang beredar yang negatif menyebabkan output menurun.

Studi lain yang dilakukan oleh De Long dan Summers (1988); dan Karras (1996) tentang ekonomi AS dan Eropa juga menyatakan bahwa output riil relatif lebih sensitif terhadap gonjangan moneter negatif dibandingkan gonjangan moneter positif. Holmes (2000) memaparkan survei tentang asimetri dengan membedakan dampak output dari kebijakan moneter negatif dan positif di daerah Inggris. Dalam studi ini, kami menggunakan istilah asimetri untuk menyoroti dampak diferensial dari kebijakan moneter (diukur dengan peningkatan suku bunga sebesar 1\%) pada output di seluruh daerah dan negara.

8 Selain itu, Guiso (1999)menyatakan bahwa gonjangan terhadap spesifikasi model biasanya berbeda-beda di negara-negara Eropa (variabel mana yang dimasukkan dan bagaimana gonjangan diidentifikasi), yang tercermin baik dalam hal sizemaupun time-path. Mojon dan Peersman (2001) menyatakan bahwa bukti tentang perbedaan antar negara dalam transmisi moneter yang dipaparkan oleh suatu studi tidaklah kuat dalam seluruh studi, hal ini sebagian dikarenakan besaran dari estimasi gonjangan kebijakan moneter berbeda-beda di negara-negara UE. Terkait masalah robustness, Peersman (2004) menolak argumen bahwa kebijakan moneter yang diambil di Eurozone memiliki dampak heterogen.

9 Survei terkait lainnya dilakukan oleh Cechetti (1999) dan Elbourne dan de Haan (2004), dengan menggunakan metode penelitian yang berbeda. Cechetti menyatakan bahwa perbedaan sistem hukum memainkan peran kunci dalam transmisi moneter yang berbeda-beda di negara-negara Eropa, sementara Elbourne dan de Haan hanya menemukan sedikit kaitan antara sistem hukum dengan struktur keuangan yang bisa menyebabkan perbedaan dalam transmisi moneter. 
Dibandingkan dengan studi-studi sebelumnya, makalah ini memperluas analisa dalam beberapa hal. Pertama, untuk mengatasi masalah komparabilitas, sampel kami hanya dibatasi pada studi-studi yang hanya menggunakan metodologi Vector Autoregressive $(V A R)^{10}$, dan sama-sama melaporkan dampak dari gonjangan moneter kontraksioner (contractionary monetary shock) (sebagaimana diukur melalui peningkatan suku bunga sebesar satu persen) pada output. ${ }^{11}$ Kedua, studi ini menggunakan skema pembobotan yang lebih luas dalam model meta regresi untuk mengetahui heterogenitas studi. Ketiga, seperangkat conditioning variable digunakan untuk menemukan variabel potensial yang bisa menjelaskan variasi dampak output, dan pemilihannya didasarkan pada teori yang ada. Terakhir, studi kami lebih menekankan pada dampak output pada tingkat regional dan bukannya pada tingkat negara. ${ }^{12}$

Makalah ini disusun sebagai berikut. Bagian 2 akan membahas secara ringkas latar belakang teoritis dan jalur transmisi moneter pada umumnya. Bagian 3 menjelaskan struktur dari spesifikasi model, data dan sampel meta-analisis. Bagian 4 memaparkan meta analisis dari peran karakteristik studi dan faktor-faktor penting lainnya yang bisa menjelaskan variasi dalam estimasi dampak kebijakan moneter terhadap output. Bagian berikutnya membahas perbedaan transmisi moneter, dan kemudian mencoba menarik trajektori dari perkembangan output. Bagian akhir adalah kesimpulan.

\section{TEORI}

Model ekonomi konvensional telah menerangkan bagaimana kebijakan moneter bisa mempengaruhi ekonomi riil melalui sisi permintaan agregat dan karenanya, suku bunga telah lama diketahui sebagai jalur transmisi yang paling penting. Kenaikan suku bunga akan menaikkan biaya modal (dampak langsung). Hal ini kemudian akan menyebabkan penurunan komponenkomponen yang sensitif bunga dari permintaan agregat (dampak tidak langsung). Kenaikan suku bunga jangka pendek akan menurunkan harga aset, yang kemudian akan menurunkan pengeluaran konsumsi melalui dampak kekayaan (wealth effect), dan pengeluaran investasi melalui Tobin's q-effect.

10 Setelah berfokus menganalisa model yang sama dalam berbagai studi, kami berharap bisa meminimalkan kemungkinan munculnya dampak diferensial kebijakan moneter dari perbedaan-perbedaan metodologis dan bukannya dari perbedaan ekonomi. Selain itu, masalah "membandingkan apel dengan jeruk" yang umumnya timbul dalam meta-analisis, terutama dalam ekonomi bisa dihindari.

11 Meskipun dampak riil dari gonjangan moneter pada harga-harga juga penting, namun fokus makalah ini hanya terbatas pada respon output setelah terjadinya gonjangan moneter. Disamping itu, sebagian besar studi menunjukkan bahwa dampak harga dari kebijakan moneter cenderung membingungkan (puzzle), dan dikenal dengan sebutan 'price-puzzle'.

12 Area regional yang disebutkan di sini, bisa diklasifikasikan secara sempit seperti negara bagian atau provinsi dalam satu negara berdaulat yang memiliki kebijakan moneter nasional yang sama; atau, secara luas, sebagai kumpulan negara-negara independen yang bersatu di bawah uni moneter seperti di Eurozone. Sementara studi GS didasarkan pada tingkat negara. 
Jalur penting lain dimana pengetatan kebijakan moneter cenderung menekan aktivitas ekonomi adalah jalur kredit. Dalam sudut pandang kredit, dampak kontraksioner dari kebijakan moneter ditransmisikan secara luas melalui penurunan pinjaman bank. Selain itu, jalur nilai tukar dari kebijakan moneter adalah hal yang penting terutama di negara kecil dengan ekonomi terbuka. Pengetatan moneter mempengaruhi nilai tukar nominal dan menyebabkannya terapresiasi, sementara rigiditas nominal terjadi dalam jangka pendek, dan karenanya menyebabkan apresiasi nilai tukar riil. Kemudian, hal ini bisa menekan ekspor neto. ${ }^{13}$

Sementara itu, beberapa peneliti menunjukkan arti dampak sisi penawaran atau dampak biaya dari kebijakan moneter, seperti Blinder (1987), Christiano et al. (1997), dan lain-lain. Kenaikan suku bunga nominal bisa memiliki dampak output terutama melalui kenaikan biaya produksi yakni melalui jalur modal kerja (untuk lebih rinci, lihat Barth dan Ramey, 2001). Secara umum, kebijakan moneter kontraksioner juga menyebabkan penurunan output dari dampak penawaran atau dampak biaya. ${ }^{14}$

Dari sudut pandang empiris, model Vector Autoregressive(VAR) telah banyak digunakan untuk mengkaji mekanisme transmisi kebijakan moneter (lihat survei yang dilakukan oleh Leeper et al.,1996 dan oleh Christiano et al., 1999). VAR memiliki beberapa kelebihan; karena semua variabel diperlakukan secara simetris, maka tidak ada keharusan untuk membagi antara variabel eksogen dengan endogen (Sims, 1980, 1986; Bernanke, 1986). Dalam konteks regional, beberapa analisa terbaru misalnya Carlino dan De Fina (1999), Fratantoni dan Schuh (2003), mengadopsi model VAR untuk melihat dampak limpahan aktivitas ekonomi (spillover effect) antar daerah.

Pada prinsipnya, VAR terdiri atas seperangkat persamaan dimana tiap-tiap variabel dalam sistem ditentukan oleh nilai lag dan lag dari semua variabel lain dalam sistem. VAR bisa dinyatakan dalam moving-average representation berikut ini ${ }^{15}$ :

$$
B(L) y_{t}=u_{t^{\prime}}
$$

dimana, $y_{t}$ adalah vektor $3 \times 1$ yang terdiri atas log difference tingkat harga, output dan tingkat suku bunga jangka pendek. $B(L)$ adalah polinomial pada lag operator dengan koefisien matriks 3×3. Gonjangan terhadap sistem, $\varepsilon_{t}^{p}, \varepsilon_{t}^{y,} \varepsilon_{t}^{i}$, diwakili oleh vektor $u_{t}$. Maka $B(L)=I-B^{l} l^{2}-$ $B^{2} L^{2} \ldots B^{n} L^{n}$; dimana $n$ adalah panjang lag VAR. Salah satu fitur paling relevan adalah fungsi

13 Karena mekanisme transmisi moneter dibahas cukup intensif dalam buku-buku teks tentang makroekonomi atau moneter, maka untuk meringkasnya kami membatasi pembahasan tentang topik ini (detail lebih lanjut lihat, Mishkin, 1995, 1996 ; Taylor, 1995).

14 Kemudian, jika gonjangan menyebabkan kenaikan harga, permintaan akan merespon dengan arah yang berlawanan, maka output akan jatuh sejalan dengan hal itu. Karenanya, gonjangan kebijakan bisa memiliki dampak penawaran maupun dampak permintaan. Barth dan Ramey (2001) menekankan bahwa dalam pemikiran ini, bisa muncul konsep non-netralitas uang karena beberapa tipe rigiditas.

15 Penjelasan lebih jauh tentang metodologi VAR bisa dilihat dalam buku-buku teks Time-Series Econometrics, seperti Hamilton (1994) dan Enders (2004). 
impulse-response yang merangkum interaksi dinamis antar variabel, misalnya antara harga, pertumbuhan output dan suku bunga (sebagai gonjangan kebijakan) sebagaimana tercantum di atas. Selain itu, Cochrane (1998) menekankan bahwa fungsi impulse-response menunjukkan sejarah, nilai rata-rata dari beberapa variabel ekonomi relevan setelah adanya gonjangan kebijakan moneter. Untuk lebih memahami penerapan VAR dalam berbagai studi moneter, bagian selanjutnya akan membahas penerapan meta-analisis di bidang ini.

\section{METODOLOGI}

Meta-analisis pertama kali diajukan oleh Karl Pearson pada tahun 1904. Meta-analisis mengacu pada analisa statistik dari sekumpulan hasil dalam jumlah besar dari berbagai studi dengan tujuan untuk mengintegrasikan hasil temuan. Secara sederhana Stanley dan Jarrel (1989) menyatakan bahwa metode ini adalah analisa terhadap analisa-analisa empiris yang mencoba mengintegrasikan dan menjelaskan literatur tentang beberapa parameter penting khusus. Sebagaimana ditekankan oleh Florax et al. (2002), meta-analisis memberikan alat bagi para peneliti untuk membandingkan dan/atau menggabungkan hasil dari berbagai studi yang memiliki pengaturan (set-up) yang sama (atau, secara alternatif, perbedaan dalam pengaturan yang bisa dikendalikan). ${ }^{16}$

Pada awalnya meta-analisis sering digunakan dalam ilmu medis dan publikasi pertama adalah Extra-sensory perception after sixty years, yang ditulis oleh psikolog dari Duke University, J. G. Pratt, J. B. Rhine, dan rekan (Bosch, H, 2004). Saat ini, meta-analisis banyak digunakan di berbagai bidang, termasuk psikologi, ilmu sosial, pemasaran, pendidikan dan terutama ekonomi. Stanley dan Jarrell (1989) memulai penggunaan meta-analisis dalam ilmu ekonomi, dan kemudian banyak diikuti oleh ahli-ahli lain, seperti Card dan Krueger (1995) dalam ekonomi ketenagakerjaan, Smith dan Huang (1995) dalam ekonomi lingkungan, dan Nijkamp dan Poot (2004) dalam makroekonomi dari kebijakan fiskal.

Secara khusus dalam makroekonomi dan ekonomi moneter, beberapa studi telah mencoba menerapkan meta-analisis untuk mengidentifikasi, misalnya, dampak keanggotaan dalam currency union terhadap perdagangan bilateral yang dilakukan oleh Rose dan Stanley (2005), dan elastisitas pendapatan dari permintaan uang oleh Knell dan Stix (2005).

Karenanya penggunaan meta-analisis sesuai untuk studi ini dalam menganalisa perbedaanperbedaan studi yang ditemukan dalam hal sejumla besar variasi elastisitas output di daerah atau negara-negara dalam uni moneter. Penggunaan meta-analisis juga berarti memiliki 
keunggulan utama dari metode ini yang pada dasarnya bersifat statistik: metode ini bisa memberikan estimasi yang lebih kuat tentang besaran dampak yang sebenarnya (dan mungkin memberikan hasil temuan yang lebih baik) daripada pendekatan-pendekatan lain seperti tinjauan literatur naratif atau tinjauan penghitungan suara. Sebagaimana disampaikan oleh Stanley (2005), pendekatan penghitungan suara memiliki beberapa masalah seperti bias metodologis dan keputusan yang dipertanyakan atau hasil yang kontroversial. ${ }^{17} \mathrm{Di}$ atas semua itu, Florax et al. (2002) berpandangan bahwa meta-analisis lebih tidak rentan terhadap 'subjektivitas' dan bisa membantu menerangkan berbagai variasi dalam estimasi empiris yang seringkali dijumpai dalam penelitian empiris.

\section{III.1. Model Meta-Regresi}

Spesifikasi umum dari model meta-regresi kami adalah sebagai berikut.

$$
Z_{j}=\alpha+\sum \beta_{i} X_{i j}+\sum \gamma_{i} Y_{i j}+\varepsilon_{j} \quad i=1,2, \ldots, K ; j=1,2, \ldots \ldots, L
$$

Dimana $Z_{j}$ mewakili besarnya dampak akibat kenaikan suku bunga sebesar satu persen dalam studi $j$. Karena kami telah menentukan empat parameter besaran dampak yakni tingkat maksimal, kuartal keempat, kuartal keenambelas dan time-elapsed pada maksimal, maka kami bisa mengeneralisasikan model di atas ke dalam empat spesifikasi model berbeda. Sebelumnya kami telah membahas dua variabel independen meta, yakni karakteristik studi $\left(X_{i j}\right)$ dan conditioning variables $\left(Y_{i j}\right)$. $\alpha, \beta$, dan $\gamma$ adalah parameter yang akan diestimasi, sedangkan $\varepsilon$ adalah kesalahan (error).

Model ini akan diestimasi dengan empat cara. Pendekatan pertama adalah menggunakan estimator ordinary least square (OLS). Namun sebagaimana ditunjukkan oleh White (1984), standard error OLS bisa saja salah jika ada heteroskedastisitas daerah/negara atau korelasi kesebayaan (contemporaneous correlation) pasangan daerah/negara dari error, dan karenanya estimator tidak efisien. ${ }^{18}$ Karena kedua fenomena tersebut berpotensi muncul dalam data kami, maka kami menggunakan robust standard error atau Huber-White standard error, untuk memperbaiki masalah heteroskedastisitas dan cluster autocorrelation. ${ }^{19}$ Secara umum, metode ini tidak mengubah estimasi koefisien namun meningkatkan estimasi standard error. Dalam

17 Meskipun masalah-masalah itu juga bisa muncul dalam meta-analisis, namun secara umum masalah tersebut lebih parah dalam kajian naratif atau penghitungan suara.

18 Masalah region/country-pair correlation muncul karena katakanlah, Jerman dan Belanda memiliki hubungan ekonomi khusus, atau negara bagian New York dan Michigan di AS memiliki hubungan ekonomi khusus.

19 Cluster autocorrelation mengacu pada pengamatan yang independen pada kluster (kelompok), namun tidak selalu independen dalam kluster 
beberapa studi meta baru-baru ini, penggunaan pendekatan Huber-White bisa ditemukan misalnya dalam Gorg dan Strobl (2001), dan Abreu et al. (2005).

Kemudian, adalah perhatian utama kami untuk memeriksa robustness dari hasil regresi yang telah disebutkan sebelumnya dengan menggunakan beberapa skema pembobotan (weighting scheme). Pendekatan ini juga relevan dengan melihat bahwa berbagai studi/publikasi memiliki endowment difference, terutama kualitas studi dan beberapa variasi yang tak teramati (unobserved variation). ${ }^{20}$ Untuk melakukannya, kami bergantung pada weighted (generalized) least square (lihat Gujarati, 2003; Greene, 2000). ${ }^{21}$ Weichselbaumer dan Winter-Ebmer (WW) (2005) juga menggunakan teknik ini dalam studi meta-analisis, kemudian mereka menambahkan bahwa penggunaan skema pembobotan tertentu ditujukan untuk mengatasi ketiadaan independensi dalam berbagai estimasi yang tersedia untuk tiap-tiap studi. ${ }^{22}$

Untuk mengatasi variasi dalam kualitas studi, sembari menghindari kemungkinan bias seleksi karena pilihan subjektif oleh peneliti23, makalah ini memberikan bobot pada studi berdasarkan pada peringkat jurnal yang dipaparkan dalam Kalaitzidakis et al. (2003). Kemudian kami memeriksa ulang dengan melihat pada peringkat The Tinbergen Institute. ${ }^{24}$

Selanjutnya, kami juga memberikan akar pangkat derajat kebebasan (square root of the degrees of freedom) sebagai bobot alternatif untuk menyatakan tingkat presisi dari estimasi, karena nilai absolut $t$-statistic tidak bisa ditemukan dalam kasus kami. ${ }^{25}$ Bobot terakhir yang digunakan adalah besaran (size) sampel yang mengacu pada jumlah daerah atau negara yang digunakan dalam masing-masing studi.

Disamping itu, karena metode dasar dari studi meta kami didasarkan pada metode crosssection regression, maka kami merata-ratakan data variabel penjelas (eksplanatory variable)

20 Wolf (1986); Weichselbaumer dan Winter-Ebmer (2005); Knell dan Stix (2005) memaparkan beberapa pembahasan dan aplikasi tentang bagaimana cara pembobotan meta-regression. Sebaliknya, Krueger (2003) menolak studi pembobotan seperti berdasarkan jumlah estimasi, dan sebaliknya dia mengajukan pembobotan setara sebagai pendekatan yang lebih sesuai.

21 Untuk regresi dengan data cross-section, biasanya diasumsikan bahwa error term tidak berkaitan, sementara dalam teori ekonometrik diketahui pula bahwa varians tidak konstan pada individu (masalah heteroskedastik). Jika tidak, masalah tersebut menjadikan estimator OLS tidak lagi efisien (varians minimal), dan karenanya uji t dan F ber dasarkan pada estimator OLS bisa menyesatkan, dan menghasilkan kesimpulan yang keliru (Gujarati, 2003; Kennedy, 2008). Disamping itu, WLS digunakan jika true variance diketahui. Jika tidak diketahui, maka kita hanya bisa bergantung pada interalia, estimator Huber/White/sandwich. Akan tetapi, Greene (2000) mengajukan estimator alternatif seperti GLS (generalized least square) dua tahap dan maximum likelihood, karena metode biasa mungkin tidak bisa berfungsi dengan baik jika model general heteroscedastic regression memiliki banyak parameter yang harus diestimasi.

22 Istilah ketiadaan independensi mengacu pada berbagai studi yang dilakukan oleh para penulis berbeda yang menggunakan data yang sama atau sangat mirip namun metode yang berbeda, dan karenanya menimbulkan kekhawatiran bahwa data ini tidak diambil dari sampel acak.

23 GS menyebutkan masalah bias seleksi dalam kualitas study, dimana panjang periode sampel dari studi primer digunakan sebagai proxy.

24 Kunjungi http://www.tinbergen.nl/.

25 Berdasarkan pada teori sampling, telah banyak diketahui bahwa nilai absolut dari t-statistic setara dengan akar pangkat dari derajat kebebasan dalam regresi. 
terutama conditioning variables. Sejalan dengan itu, dimensi waktu untuk perata-ratana akan disesuaikan dengan rentang waktu (time span) dalam studi. Pendekatan ini mudah dijalankan dan bisa meminimalkan kemungkinan bahwa hasilnya akan bergantung pada data tahun tertentu, dan pendekatan ini juga membantu mengendalikan dinamika siklus usaha. ${ }^{26}$

\section{III.2. Meta-Data dan Variabel Penjelas (Explanatory Variables)}

Ada cukup banyak studi tentang bagaimana pengaruh kebijakan moneter pada ekonomi regional serta respon negara-negara tersebut pada gonjangan kebijakan bersama. Untuk mengumpulkan studi empiris di bidang transmisi moneter sebagai sampel, kami mengikuti pendekatan standar dan menggunakan Econlit (Economic Literature Indec), yang banyak digunakan sebagai basis data penelitian yang populer dan mudah diakses.

Pada awalnya studi-studi yang relevan dicari dalam basis data ini, cukup dengan mengetikkan kata kunci berikut ini sebagai acuan: '(monetary policy*, atau macroeconomic policy $\left.^{\star}\right)$, (output*, atau growth*) dan (region*, atau country*)'. Sejauh ini, pencarian Econlit menghasilkan total 42 studi.

Akan tetapi, karena semua studi yang ditemukan cenderung memperlihatkan perbedaan besar dalam banyak aspek, maka agar memiliki pendekatan meta-analitis yang tepat, kami perlu menerapkan beberapa kriteria seleksi untuk studi-studi tersebut. Pertama, metodologi yang digunakan dalam studi tersebut adalah metode vector autoregressive (VAR) yang mendapatkan momentumnya pada awal tahun 1990an; sementara sebelumnya sebagian besar studi bergantung pada model struktural kecil dan persamaan bentuk reduksi (reduced form equations). ${ }^{27}$ Telah diketahui secara luas bahwa metodologi state of the art memperlihatkan beberapa fitur robustness terutama dalam mengidentifikasi peran kebijakan moneter dan tipe gonjangan lain yang bisa mempengaruhi aktivitas ekonomi (lihat Faust, 1998; Elbourne dan de Haan, 2004).

Kedua, studi tersebut memaparkan respon regional terhadap gonjangan kebijakan moneter kontraksioner dalam hal persentase perubahan output akibat kenaikan suku bunga yang tidak diharapkan sebesar satu persen poin atau 100 basis poin. ${ }^{28} \mathrm{Hal}$ ini mempermudah

26 CD (1999) yang awalnya mengemukakan argumen ini.

27 Lihat, misalnya, Fishkind, 1977; Miller, 1978; Garrison dan Chang 1979. Karena kriteria ini, kami akan mengabaikan studi-studi yang menggunakan pendekatan selain VAR. Oleh karena itu, kami harus menghilangkan lebih dari setengah artikel yang sudah terkumpul.

28 Sebagaimana disebutkan sebelumnya, VAR juga memungkinkan jalur gonjangan moneter lain pada ekonomi, seperti jalur kredit dan jalur nilai tukar. Akan tetapi, kami membatasi analisa kami pada jalur yang paling konvensional, yakni suku bunga, yang diketahui memiliki dampak langsung pada perkembangan output dan juga digunakan oleh bank sentral sebagai instrumen kebijakan utama. Sementara itu, penyimpangan dari jalur lain berada diluar ruang lingkup makalah ini. 
kami dalam membandingkan hasil-hasil ekonometrik dari berbagai sampel, karena hal ini mengindikasikan hubungan semi-elastisitas. Sejalan dengan itu, sampel juga bisa menunjukkan dampak waktu (timing effect) dari tindakan moneter. Fokus kami hanyalah untuk mengkaji dampak kontraksioner dari kebijakan moneter pada output. Survei komprehensif yang dilakukan oleh Florio (2004) menunjukkan bahwa penurunan output setelah terjadinya goncangan kebijakan moneter negatif nampaknya lebih besar dibandingkan ekspansi yang didorong oleh gonjangan positif dengan ukuran yang sama. Secara umum, sebagaimana diprediksi oleh teori bahwa kebijakan moneter cenderung lebih efektif dalam mendorong aktivitas ekonomi pada periode resesi dibandingkan pada periode pertumbuhan ekonomi.

Berdasarkan pada kriteria seleksi, kami mengumpulkan sejumlah studi, yang mengarahkan kami pada sekitar 285 sampel pengamatan, yang sebagian besarnya dipublikasikan di jurnal dan publikasi terkenal (kertas kerja). Respon output akibat gonjangan moneter berdasarkan pada model VAR ditunjukkan oleh Impulse Response Functions (IRF). ${ }^{29}$ Sebagai gambaran, kami menunjukkan pada Gambar 1 di bawah beberapa pola umum dari dampak output dan time path, yang digambarkan ulang dari grafik impulse response function pada sampel-sampel kami. Secara umum, bentuk kurva menunjukkan penurunan pertumbuhan output regional setelah terjadi kenaikan suku bunga bank sentral (jangka pendek) yang tidak diharapkan sebesar satu persen. ${ }^{30}$

Langkah kami selanjutnya adalah menurunkan besaran dampak dari grafik IRF, dan perhatian kami khususnya adalah estimasi empat poin dari besaran dampak yang terkait dengan dampak output dan waktu. ${ }^{31}$ Dampak output mengacu pada level maksimal, level pada kuartal keempat, dan level pada kuartal keenambelas; sedangkan dampak waktu mengacu pada timeelapsed pada dampak maksimal.

Dampak maksimal mengukur dampak tertinggi (terbesar) dari gonjangan moneter (secara absolut) dan merupakan titik terendah pada grafik. Pengamatan kuartal-keempat bisa menjadi ukuran proxy untuk dampak jangka pendek, sedangkan dampak kuartal-keenambelas bisa

29 Studi VAR biasanya memaparkan dampak umpan balik (feedback effect) dari inovasi gonjangan melalui grafik Impulse Response function (IRF).

30 Akan tetapi, perlu diingat bahwa pola output cenderung menunjukkan respon positif kecil pada awal periode gonjangan kebijakan, sebagaimana dinyatakan oleh teori moneter standar bahwa kebijakan moneter biasanya memiliki dampak time-lag (keterangan lebih lanjut, lihat Walsh, 2003).

31 Karena kami perlu mendapatkan estimasi dari grafik IRF, maka ukuran grafik pada studi dasar telah diperluas agar kami bisa mengekstraksi presisi estimasi tertinggi. Untuk melakukannya, kami melakukan pemeriksaan komparatif dengan mengambil sekitar 20 persen estimasi yang ditemukan dalam studi primer yang memaparkan dampak ukuran beserta dengan VAR IRF. Kemudian, kami menggunakannya sebagai estimasi kendali untuk memverifikasi apakah koefisien yang didapat dari grafik tidak tepat. Akan tetapi, hasilnya memperkuat bahwa teknik pertama biasanya menghasilkan magnitude koefisien yang sama dengan yang didapat dalam studi-studi tersebut. 
mewakili dampak jangka menengah. ${ }^{32}$ Estimasi waktu yang didapat juga bisa berguna untuk menyoroti kecepatan gonjangan kebijakan sebelum mencapai level maksimal (untuk lebih detail lihat Subbagian III.4). Dalam analisa meta-regresi, keempat tipe besaran dampak akan digunakan sebagai variabel dependen.

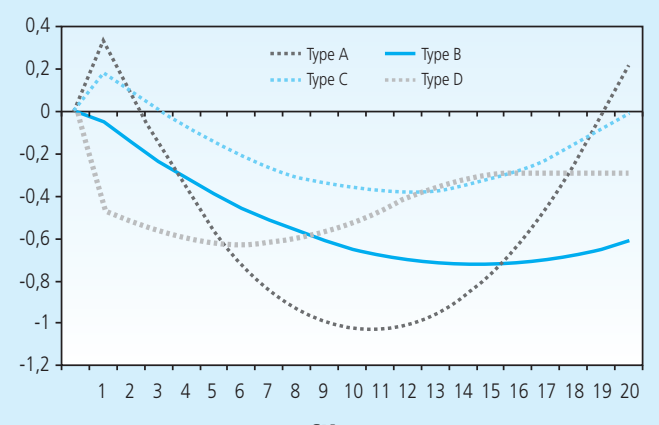

Grafik IV.1

Beberapa pola umum dari grafik IRF yang menjabarkan besaran (size) dan waktu (timing) dampak output dari tindakan moneter (dibuat kembali dari studi primer).

Variabel penjelas (explanatory variable) dalam meta-analisis bisa dibedakan menjadi variabel 'fitur studi primer' dan 'conditioning'. Variabel pertama bisa dikategorikan ke dalam tipe spesifikasi model, struktur data dan karakteristik waktu sebagaimana dibahas di bawah ini.

Tipe batasan (masalah identifikasi) - Permodelan VAR menawarkan banyak fleksibilitas terutama dalam menentukan identifikasi dan mengenakan batasan (restriction). Untuk menerangkan perbedaan-perbedaan ini dalam berbagai studi, kami membedakan lima jenis identifikasi, pertama. VAR standar berdasarkan pada skema identifikasi rekursif (recursive identification scheme) dan dekomposisi Choleski (Sims, 1980). Karena model ini tidak mengenakan batasan struktural dari teori ekonomi tertentu, hanya bergantung pada dan "biarkan data berbicara", maka dikenal dengan sebutan permodelan a-teoritis.

Tipe batasan yang kedua menggunakan dekomposisi non-rekursif dan menyatakan bahwa beberapa variabel yang tidak bisa saling mempengaruhi pada saat bersamaan. Sebagai contoh,

32 Kuartal keenambelas dipilih sebagai ukuran (measure) untuk dampak jangka menengah. Akan tetapi, GS (2004) menggunakan tahun kelima (= kuartal ke-20) sebagai ukuran untuk dampak jangka panjang. Sebagaimana diprediksi dalam teori, uang cenderung netral dalam jangka panjang, dan karenanya alih-alih terjebak dalam perdebatan ini, kami mempertimbangkan dampak jangka pendek dan juga jangka menengah. Selain itu, model dampak jangka panjang cenderung sangat bervariasi dalam berbagai studi, terutama diakibatkan oleh kenyataan bahwa beberapa studi mengenakan batasanjangka panjang, atau dikenal dengan sebutan Structural VAR. 
gonjangan pada suku bunga tidak memiliki contemporaneous effect pada output, atau ada lag-period (Bernanke dan Blinder, 1992). Tipe lainnya adalah batasan apriori teoritis jangka panjang untuk mengidentifikasi struktur ekonomi dari bentuk reduksi (reduced-form) (Blanchard dan Quah, 1989; Shapiro dan Watson, 1988). ${ }^{33}$

Sementara itu, skema identifikasi oleh Gali (1992, 1999) mencoba menggabungkan hambatan jangka pendek (contemporaneous) dan jangka panjang. ${ }^{34}$ Terakhir, spesifikasi dinamis VAR juga memungkinkan King et al. (1991) untuk menggunakan model cointegrated, dimana semua variabel memiliki derajat stationer yang berbeda namun beberapa gabungan linear dari variabel adalah statis. Kointegrasi bisa diuji dengan teknik Johansen. ${ }^{35}$ Selanjutnya, dalam memaparkan hasil regresi, demi kemudahan maka semua hambatan ini disebut dengan vara, varb, varc, vard, dan vare.

Dimensi model - Dimensi sistem VAR pada dasarnya didasarkan pada sejumlah variabel (penjelas). Penggunaannya dalam model kami adalah karena kenyataan bahwa berbagai model berbeda dalam berbagai studi menggunakan dimensi yang berbeda untuk mewakili struktur ekonomi yang berbeda dan fungsi reaksi yang berbeda dari berbagai negara dan daerah. Kami mempertimbangkan perbedaan-perbedaan tersebut dengan menggunakan variabel dummy terpisah, dan bisa dibedakan sebagai berikut. Jenis pertama adalah dimensi standar yang terdiri atas empat sistem variabel yakni harga, output, suku bunga, dan uang. Varian lain menambahkan variabel nilai tukar, dan varian terakhir mencakup nilai tukar, harga (komoditas) minyak dan suku bunga asing ke dalam dimensi standar.

Karakteristik data - Studi ini menggunakan variabel dummy berbeda untuk pengamatan yang menggunakan berbagai ukuran berbeda untuk dampak output dari kebijakan moneter. Ukuran output yang digunakan bergantung pada lokasi geografis dari studi; studi AS umumnya menggunakan pendapatan pribadi negara bagian, sementara studi Eropa menggunakan Produk Domestik Bruto (PDB), atau indeks produksi industri (industrial production index / IPI). ${ }^{36}$ Variasi suku bunga jangka pendek yang digunakan seperti suku bunga bank sentral, atau suku bunga pasar uang juga akan terlihat pada variabel dummy.

Karakteristik temporal - Variasi temporal pada berbagai studi sampel dan diklasifikasikan sebagai berikut. Dengan mengikuti pendekatan ekletik, kami membuat daftar beberapa ukuran

33 Batasan jangka panjang biasanya berupa bahwa gonjangan pada satu variabel memiliki dampak jangka panjang pada variabel lain, karenanya gonjangan moneter tidak boleh memiliki dampak jangka panjang pada output karena adanya netralitas moneter.

34 Skema ini juga mengidentifikasi gonjangan teknologi sebagai satu-satunya gonjangan yang berdampak permanen pada produktivitas, dengan kata lain gonjangan kebijakan moneter tidak memiliki dampak jangka panjang pada output.

35 Untuk keterangan lebih lanjut tentang pembahasan mengenai batasan dan identifikasi dalam model VAR bisa ditemukan dalam Enders (2004) dan Favero (2001)

36 Untuk kemudahan, selanjutnya kami akan menggunakan PDB untuk mewakili ukuran-ukuran lain. 
yang berpotensi mewakili dimensi waktu dari data: titik tengah periode sampel, tahun awal sampling, akhir periode sampel, panjang waktu periode sampel dan dummy dalam dekade, yakni 1960an, 1970an, 1980an, dan 1990an ke atas. ${ }^{37}$ Selain itu, kami juga mempertimbangkan perbedaan dalam panjang time-lag pada sampel kami. Terakhir, unit-waktu data yang digunakan dalam berbagai studi seperti data kuartal dan bulanan dibedakan dengan menggunakan variabel dummy terpisah.

Kelompok kedua dari variabel penjelas dalam meta-analisis adalah conditioning variable. Pada dasarnya variabel ini adalah seperangkat variabel kendali (control variable) yang dimaksudkan untuk mengetahui faktor-faktor relevan lain yang terdiri atas variabel makroekonomi dan finansial serta karakteristik lokasi geografis. ${ }^{38}$

Kontribusi sektor manufaktur dan konstruksi terhadap PDB - Ukuran ini umumnya digunakan untuk menunjukkan intensitas modal (lihat Schunk, 2005). Karenanya, ukuran ini bisa menjadi proxy yang baik untuk mengetahui struktur ekonomi dari daerah tertentu, karena ukuran ini menyoroti jumlah modal yang digunakan terkait dengan faktor-faktor produksi lain, seperti tenaga kerja. ${ }^{39}$

Variabel finansial - Sebagaimana diprediksi oleh teori, variabel finansial bisa mempengaruhi variasi dalam kekuatan transmisi moneter pada berbagai lokasi geografis. Cecchetti (1999) menggunakan beberapa indikator finansial untuk menyoroti peran struktur keuangan dalam menjelaskan perbedaan dampak moneter di berbagai negara Eropa. Dengan mengikuti pendekatan yang dia gunakan, studi ini menggunakan rasio kapitalisasi pasar modal terhadap PDB sebagai ukuran ketersediaan keuangan alternatif.

Sementara itu, beberapa studi lain menggunakan tingkat pembangunan sektor keuangan dalam menjelaskan variasi dalam pertumbuhan antar negara. Dengan menggunakan pendekatan ini, untuk mengetahui variasi pendalaman sektor keuangan (financial deepening) di daerah itu maka kami menggunakan jumlah kantor bank (per 100.000 orang) dan rasio kredit ke perusahaan swasta terhadap PDB. Indikator rasio kredit-PDB ini telah dipertimbangkan oleh King dan Levine (1993) dan Levine, et. Al (LLB) (2000) sebagai ukuran dari tingkat pembangunan

37 Variabel terakhir mengacu pada De Grauwe dan Storti (2004).

38 Seperangkat variabel makroekonomi dan finansial dimasukkkan sebagai variabel penjelas (bersama dengan variabel-variabel lain) dalam model regresi kami untuk mengetahui mengapa ada banyak variasi elastisitas output pada berbagai studi. Berdasarkan pada simulasi yang dilakukan oleh Koetse et al. (2005) dan Keef dan Roberts (2004), Abreau et al. (2005) menyatakan bahwa meskipun dalam banyak meta-analisis spesifikasi dari conditioning variabel dianggap biasa, namun hal ini menunjukkan perbandingan yang bermanfaat dan secara statistik tidak bias. Sumber data conditional variable adalah dari indikator utama ekonomi PWT 6.2., WDI, EU KLEMS, BEA dan OECD.

39 Akan tetapi, beberapa studi hanya menggunakan kontribusi sektor manufaktur terhadap ekonomi. Namun demikian, kami mengikuti pendekatan pertama, karena industri konstruksi merupakan sektor yang padat modal, dan karenanya relatif sensitif terhadap perubahan moneter. 
sektor keuangan. ${ }^{40}$ Kami mengikuti LLB dalam menggunakan kredit swasta sebagai ukuran pembangunan sektor keuangan. Ini adalah nilai kredit yang diberikan oleh perantara keuangan kepada sektor swasta, dibagi dengan PDB. Jenis kredit ini adalah ukuran pilihan (preferred measured) karena tidak memasukkan kredit yang diberikan pada sektor publik dan kredit yang diberikan oleh bank sentral dan bank pemerintah lainnya.

Besaran ekonomi (economic size) - Ukuran ini didasarkan pada nilai total produk domestic regional bruto (gross regional domestic products / GRDP) atau, PDB (pada tingkat negara) dalam Dolar AS. Kami menggunakan ukuran ini karena kenyataan adanya perbedaan besaran ekonomi antar daerah atau negara yang kami amati. Alternatif ukuran untuk besaran ekonomi adalah jumlah penduduk. Akan tetapi, kami memilih menggunakan ukuran pertama karena berkaitan dengan nilai ekonomi. ${ }^{41}$

Kontribusi ekspor terhadap PDB - Ukuran ini didasarkan pada kontribusi perdagangan barang dan jasa terhadap total PDB. Ukuran ini umumnya digunakan untuk mewakili derajat keterbukaan suatu negara atau daerah.

Beberapa studi telah membahas bagaimana perbedaan keterbukaan bisa menjadi hal penting dalam menjelaskan variasi regional terkait dengan respon terhadap gonjangan kebijakan moneter. Pertimbangkan dampak pengetatan moneter yang bisa menyebabkan perlambatan aktivitas domestik, namun daerah-daerah yang memperoleh sebagian besar pendapatannya dari luar negeri akan terhindari dari dampak suku bunga secara langsung, jadi dampaknya kurang kuat. Karenanya, suatu daerah yang relatif lebih berorientasi ekspor cenderung tidak terlalu terkena dampak gonjangan suku bunga, dan sebaliknya. Akan tetapi, kesimpulan dari literatur yang ada cenderung tidak meyakinkan. ${ }^{42}$

Karakteristik geografis - Makalah ini membahas-daerah dan negara-negara dalam satu uni moneter secara bersamaan, dimana negara-negara adalah negara independen atau berdaulat yang memiliki karakteristik tertentu, yakni lembaga, bahasa dan budaya. ${ }^{43}$ Oleh karena itu,

40 Karena keterediaan data pada tingkat regional, kami tidak bisa memasukkan semua variabel untuk mengetahui struktur ekonomi yang digunakan oleh Cechhetti (1999). Perbedaan konsep pinjaman bank kecil dan ukuran perusahaan antara AS dan negaranegara Eropa juga menjadikan kami tidak bisa menggunakannya sebagai variabel penjelas, yang umumnya ditemukan dalam studi transmisi moneter.

41 Kelebihan menggunakan baik populasi dan PDB sebagai variabel penjelas adalah bahwa secara implisit kontribusi dari PDB per kapita bisa diperhitungkan.

42 Sementara itu, Frankel dan Rose (1996; 1997) mengkaji peran rezim nilai tukar dalam pengaruhnya terhadap kriteria OCA, kemudian berpendapat bahwa nilai tukar tetap akan menyebabkan hubungan dagang lebih intens dalam negara-negara di area EMU. Kemudian mereka berkesimpulan bahwa negara-negara yang memiliki hubungan dagang yang lebih dekat cenderung memiliki siklus usaha yang lebih terkait. Namun demikian, sebagaimana disebutkan sebelumnya bahwa studi kami lebih menekankan pada jalur suku bunga yang memiliki dampak langsung dan bukannya jalur tidak langsung seperti jalur nilai tukar.

43 Sementara itu, literatur standar menyatakan bahwa karakteristik standar di berbagai daerah dalam suatu negara cenderung lebih mirip, atau tidak terfragmentasi. 
kami menggunakan variabel dummy terpisah untuk membedakan pengamatan antara tingkat regional dan negara.

\section{HASIL DAN ANALISA}

\section{IV.1. Statistik deskriptif}

Sebelum berlanjut ke analisa meta regresi, kami akan membahas secara ringkas beberapa statistik deskriptif dari empat ukuran besaran (size) dan dimensi waktu dari dampak dengan mengacu pada Grafik IV.1. Seperti disebutkan sebelumnya, ukuran ini diperoleh dari IRF studistudi yang terkait dengan penurunan output setelah adanya kebijakan moneter kontraksioner. Secara umum, sampel pengamatan yang diperoleh dari berbagai studi cenderung menunjukkan adanya variasi yang besar dalam estimasi elastisitas output.

Grafik IV.2, IV.3, dan IV.4 menunjukkan dampak output pada level maksimal, kuartal keempat, dan kuartal keenambelas setelah adanya kebijakan moneter kontraksioner. Pada gambar pertama, nilai mean dari dampak maksimal adalah 0,76\%, jadi kenaikan suku bunga sebesar satu persen poin akan diikuti dengan penurunan output maksimal sebesar rata-rata $0,76 \%$.

Selanjutnya, ukuran kuartal keenambelas sebagai proxy untuk dampak jangka menengah (seperti terlihat pada Grafik IV.3) turun sekitar 0,50\% setelah kenaikan suku bunga sebesar satu persen poin. Grafik IV.4 mewakili kuartal keempat (proxy untuk dampak jangka pendek); nilai mean dampak output akan turun 0,31\%. Untuk memeriksa rata-rata signifikansi pada tiga ukuran, kami menggunakan metode statistik standar yakni $t$-test sederhana, dan hasilnya menunjukkan bahwa secara statistik berbeda dari nol. ${ }^{44}$

Berdasarkan pada statistik Jarque-Bera, kami menemukan bahwa distribusi parameter dari angka-angka tidak terdistribusi secara normal. Rincian lebih lanjut tentang statistik deskriptif dari keempat ukuran ini bisa dilihat pada Lampiran 1.

Terakhir, Grafik IV.5 menunjukkan nilai mean dari time elapsed untuk mencapai dampak maksimal karena gonjangan adalah sekitar 8 kuartal (dua tahun). Serupa dengan pendekatan sebelumnya, kami menemukan bahwa t-test mengimplikasikan bahwa nilai 8 kuartal ini secara statistik berbeda dari nol. Uji tambahan lain menunjukkan bahwa nilainya tidak terdistribusi secara normal. 


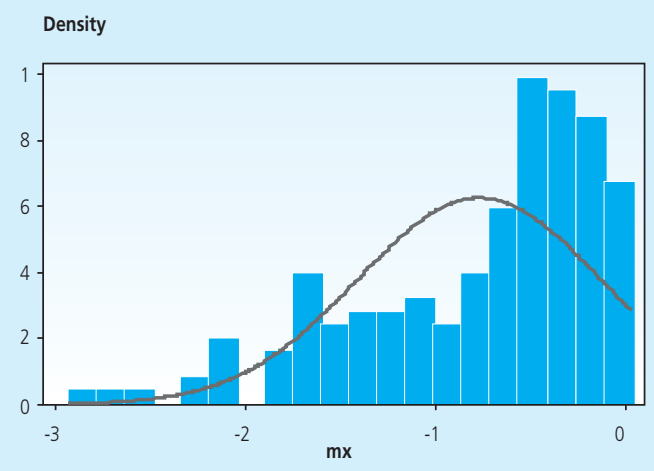

Grafik IV.2

Histogram dampak output akibat kenaikan suku bunga sebesar satu persen poin pada tingkat maksimal $(\mathrm{mx})$.

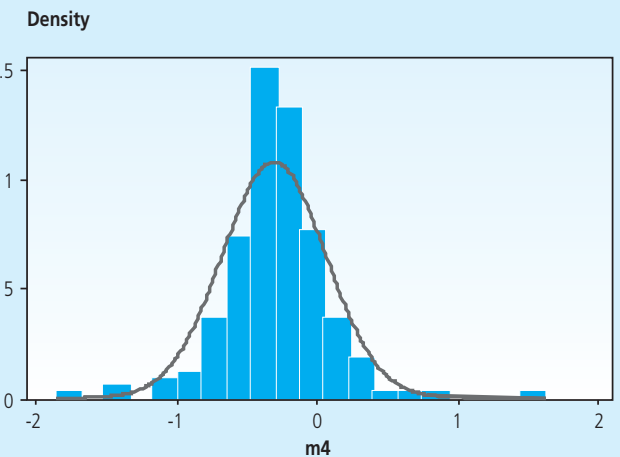

Grafik IV.4

Histogram dampak output akibat kenaikan suku bunga sebesar satu persen poin pada kuartal keempat (m4).
Density

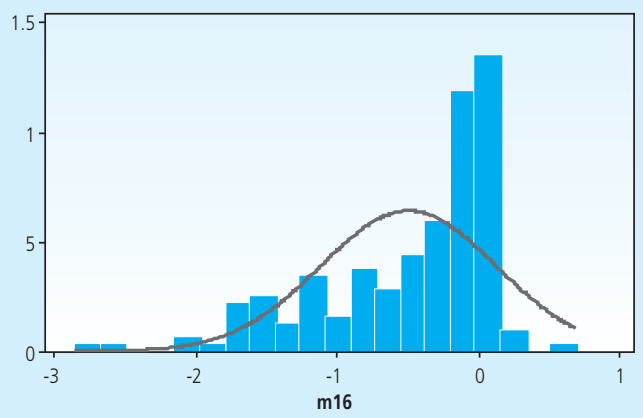

Grafik IV.3

Histogram dampak output akibat kenaikan suku bunga sebesar satu persen pada kuartal keenambelas (m16).

Density

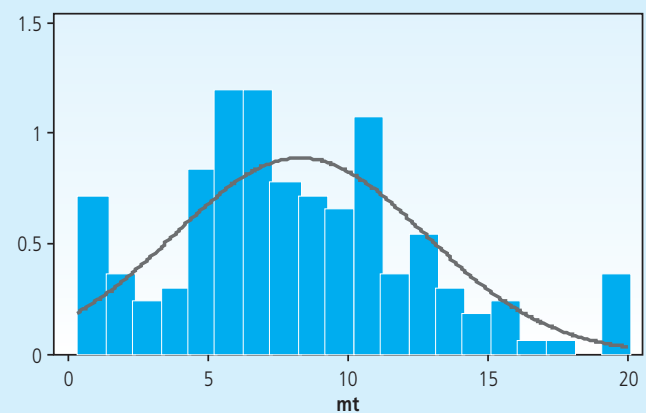

Grafik IV.5

Histogram time-elapsed pada dampak maksimal (dalam kuartal) dari gonjangan kebijakan (mt).

\section{IV.2. Hasil dan Analisa Estimasi}

Kami melanjutkan dengan memaparkan hasil meta-regresi yang diklasifikasikan berdasarkan atas spesifikasi sebelumnya seperti dampak maksimal, kuartal keempat, dampak kuartal keenambelas dan time elapsed pada dampak maksimal. Dari tabel 1 di bawah, kami merangkum hasil temuan terpenting dari regresi sebagai berikut. ${ }^{45}$ 


\begin{tabular}{|c|c|c|c|c|}
\hline Estimasi m & egresi b & $\begin{array}{l}\text { Table IV.1 } \\
\text { zarkan pada }\end{array}$ & S robust stan & dard errors \\
\hline Meta-indene & & Depe & dent variables & \\
\hline variables & $\begin{array}{l}\text { Maximum } \\
\text { effect }(\%)\end{array}$ & $\begin{array}{l}\text { The fourth } \\
\text { quarter effect }\end{array}$ & $\begin{array}{l}\text { The sixteenth } \\
\text { quarter effect }\end{array}$ & $\begin{array}{c}\text { Time-elapsed at maximum } \\
\text { effect (in quarters) }\end{array}$ \\
\hline $\begin{array}{l}\text { Share of manufacturing and } \\
\text { construction sector to GDP (\%) }\end{array}$ & $\begin{array}{r}-0,0200 * \\
(-2,27)\end{array}$ & $\begin{array}{r}-0,0176^{* * *} \\
(-3,59)\end{array}$ & $\begin{array}{r}-0,0271 * * * \\
(-3,35)\end{array}$ & $\begin{array}{r}0,0174^{*} \\
(2,22)\end{array}$ \\
\hline Share of credit to GDP (\%) & $\begin{array}{r}-0,00773^{*} \\
(-2,56)\end{array}$ & $\begin{array}{r}-0,00412^{*} \\
(-2,29)\end{array}$ & $\begin{array}{r}-0,00463 \\
(-1,58)\end{array}$ & $\begin{array}{r}0,0136^{* *} \\
(2,93)\end{array}$ \\
\hline Size of GDP & $\begin{array}{r}0,136^{* * *} \\
(3,44)\end{array}$ & $\begin{array}{r}0,00281 \\
(0,14)\end{array}$ & $\begin{array}{r}0,127 * * \\
(3,15)\end{array}$ & $\begin{array}{r}-0,109 * \\
(-2,54)\end{array}$ \\
\hline Share of export to GDP (\%) & $\begin{array}{r}0,00184 \\
(0,49)\end{array}$ & $\begin{array}{r}-0,00175 \\
(-0,66)\end{array}$ & $\begin{array}{r}0,00326 \\
(1,13)\end{array}$ & $\begin{array}{r}-0,0027 \\
(-0,45)\end{array}$ \\
\hline Regional dummy & $\begin{array}{r}-0,826^{*} \\
(-2,47)\end{array}$ & $\begin{array}{r}-0,540 * \\
(-2,52)\end{array}$ & $\begin{array}{l}-0,471 \\
(-1,47)\end{array}$ & $\begin{array}{l}0,608 \\
(1,28)\end{array}$ \\
\hline $\begin{array}{l}\text { Mid-point of observation period } \\
\text { (in quarters) }\end{array}$ & $\begin{array}{r}0,0877 \\
(1,36)\end{array}$ & $\begin{array}{r}0,121^{* * *} \\
(3,49)\end{array}$ & $\begin{array}{l}0,124 \\
(1,89)\end{array}$ & $\begin{array}{r}-0,0366 \\
(-0,40)\end{array}$ \\
\hline Restriction type (vara) & $\begin{array}{r}0,0578 \\
(0,43)\end{array}$ & $\begin{array}{r}0,0108 \\
(0,19)\end{array}$ & $\begin{array}{r}0,0104 \\
(0,08)\end{array}$ & $\begin{array}{l}-0,012 \\
(-0,07)\end{array}$ \\
\hline Restriction type (varb) & $\begin{array}{r}-0,0131 \\
(-0,06)\end{array}$ & $\begin{array}{r}0,0413 \\
(0,32)\end{array}$ & $\begin{array}{r}-0,22 \\
(-1,19)\end{array}$ & $\begin{array}{l}0,451 \\
(1,91)\end{array}$ \\
\hline Restriction type (varc) & $\begin{array}{r}-0,553 * * \\
(-2,63)\end{array}$ & $\begin{array}{r}-0,314^{*} \\
(-2,31)\end{array}$ & $\begin{array}{l}-0,175 \\
(-1,12)\end{array}$ & $\begin{array}{l}-0,158 \\
(-0,71)\end{array}$ \\
\hline Restriction type (vard) & $\begin{array}{l}-0,108 \\
(-0,60)\end{array}$ & $\begin{array}{r}-0,312^{* *} \\
(-2,71)\end{array}$ & $\begin{array}{r}0,441^{* * *} \\
(3,46)\end{array}$ & $\begin{array}{r}-0,696^{* * *} \\
(-3,67)\end{array}$ \\
\hline Quarterly data & $\begin{array}{l}0,247 \\
(1,30)\end{array}$ & $\begin{array}{l}0,116 \\
(0,97)\end{array}$ & $\begin{array}{l}-0,101 \\
(-0,64)\end{array}$ & $\begin{array}{r}1,058^{* * *} \\
(4,18)\end{array}$ \\
\hline Constant & $\begin{array}{r}-2,012^{*} \\
(-2,27)\end{array}$ & $\begin{array}{l}0,709 \\
(1,19)\end{array}$ & $\begin{array}{r}-1,35 \\
(-1,55)\end{array}$ & $\begin{array}{l}1,319 \\
(1,35)\end{array}$ \\
\hline
\end{tabular}

Temuan pertama dan yang paling mencolok adalah bahwa kontribusi sektor manufaktur dan konstruksi terhadap PDB memiliki dampak positif yang signifikan (secara absolut) di semua spesifikasi yang berbeda-beda. Artinya, negara yang memiliki intensitas modal yang besar lebih sensitif terhadap kenaikan suku bunga, dan juga bahwa durasi dampaknya lebih panjang. Kedua, kontribusi kredit terhadap PDB sebagai proxy untuk tingkat pembangunan sektor keuangan menunjukkan dampak positif dan signifikan.

Sementara itu, dampak dari besaran ekonomi (economic size) terlihat signifikan dan dengan tanda negatif. Dampak dari periode waktu pengamatan cenderung menurun seiring dengan waktu. Selain itu, perbedaan dalam spesifikasi model dalam berbagai studi memiliki kontribusi signifkan dalam menjelaskan variasi dampak output.

Patut dicatat bahwa meskipun kami telah mempertimbangkan arti penting variabel dimensi model dalam model kami, namun demikian berdasarkan pada regresi terpisah, kami tidak bisa menemukan bukti statistik untuk mendukung argumen ini. Kami juga bereksperimentasi dengan menggunakan variabel dummy untuk mengetahui variasi suku bunga yang digunakan dalam 
berbagai studi, namun hasilnya tidak signifikan. Untuk mengetahui karakteristik temporal, ada berbagai variabel temporal yang digunakan (lihat Subbagian III.2), namun demikian hanya titik tengah pengamatan yang ditemukan memiliki signifikansi secara statistik. Pada bagian berikutnya, pembahasan kami akan difokuskan pada hasil spesifikasi terbaik yang memenuhi kriteria optimalitas model.

\section{IV.2.1. Dampak output dan time path dari tindakan kebijakan moneter}

Intensitas modal - Koefisien kontribusi sektor manufaktur dan konstruksi terhadap PDB menunjukkan dampak positif (secara absolut) dan signifikan dalam tiga spesifikasi model berbeda. ${ }^{46}$ Hasil ini menunjukkan arti penting intensitas modal dalam menjelaskan variasi dampak output.

Sektor padat modal bisa memiliki tingkat sensitivitas yang kuat terhadap perubahan suku bunga. Hal ini bisa dijelaskan sebagai berikut. Pertama, hal ini berkaitan dengan jalur biaya atau sisi penawaran. Sebagaimana diprediksi oleh teori, kenaikan suku bunga akan diikuti peningkatan biaya produksi di sektor industri, sementara sisi permintaan akan merespon dengan arah berlawanan (dampak sisi permintaan) ${ }^{47}$; akibatnya output akan jatuh. ${ }^{48}$ Akan tetapi, penting untuk diingat bahwa dalam pemikiran ini, konsep non-netralitas uang bisa muncul karena beberapa jenis rigiditas.

Kedua, kenaikan suku bunga mengurangi permintaan akan barang investasi dan barang konsumsi (yang tahan lama). Jika industri-industri memiliki perbedaan sensitivitas terhadap perubahan suku bunga, dan daerah-daerah memiliki perbedaan komposisi industrial, maka teori ini bisa menjelaskan bagaimana kebijakan moneter yang seragam bisa menimbulkan dampak regional yang berbeda. Carlino dan DeFina (1998) dan Hayo dan Uhlenbrock (1999) menemukan bahwa gabungan industri memainkan peran penting dalam menentukan dampak heterogen dari respon kebijakan di berbagai negara bagian di AS, dan di berbagai daerah di Jerman. ${ }^{49}$

Serupa dengan itu, Barth dan Ramey (2001) menunjukkan bahwa industri barang-barang tahan lama di AS cenderung lebih responsif terhadap perubahan kebijakan moneter

46 Kami mengikuti Schunk (2005), untuk menggunakan kontribusi manufaktur dan sektor konstruksi, sebagai proxy untuk ukuran intensitas modal. Selain itu, Carlino dan De Fina $(1996,1999)$ berpandangan bahwa beberapa industri, seperti manufaktur dan konstruksi, sangat sensitif terhadap suku bunga.

47 Barang-barang manufaktur secara konvensional dikenal sebagai produk elastis pendapatan.

48 Lihat pembahasan sebelumnya pada Bagian 2.

49 Sebagai gambaran, sektor yang sensitive bunga, seperti manufaktur memberi kontribusi rata-rata $27 \%$ dari gross state produk (GSP) riil di daerah Great Lakes pada periode 1985-1990, namun kurang dari 13\% dari GSP riil di Rocky Mountain (lihat Carlino dan De Fina, 1999). 
dibandingkan dengan industri barang-barang yang tidak tahan lama. Di Eropa, Ganley dan Salmon (1997) dan Dedola dan Lippi (2005) ${ }^{50}$ juga menyatakan bahwa ketahanan output yang diproduksi oleh suatu sektor adalah faktor penentu penting terkait dengan sensitivitas terhadap perubahan kebijakan moneter. Hal ini terutama karena permintaan akan produk-produk tahan lama, seperti barang-barang investasi, diketahui jauh lebih terpengaruh oleh kenaikan suku bunga melalui jalur biaya modal biasa daripada permintaan akan produk tidak tahan lama seperti makanan.

Selanjutnya, konstruksi termasuk sektor perumahan/properti memiliki karakteristik regional terutama spatial fixity ${ }^{51}$, dan karenanya bisa menjadi pendorong utama dalam menjelaskan volatilitas output regional. Salah satu sumber volatilitas yang penting berkaitan erat dengan tingginya sensitivitas terhadap perubahan kebijakan moneter. Fratantoni dan Schuh (2003) menyatakan bahwa ada kaitan erat antara investasi perumahan dengan siklus usaha dan kebijakan moneter di negara-negara bagian di AS. ${ }^{52}$

Dalam literatur standar, hubungan antara pasar perumahan dengan kebijakan moneter dijelaskan melalui jalur harga aset. Karena perumahan (termasuk lahan) dianggap sebagai jenis ekuitas, maka jalurnya bisa diinterpretasikan baik dalam teori Tobin's q maupun dampak kekayaan (wealth effect). Kenaikan Tobin's q untuk perumahan awalnya didorong oleh kenaikan harga perumahan, yang kemudian menaikkan harganya dibandingkan biaya penggantian. Setelah itu, produksi akan meningkat. Selanjutnya, kenaikan harga perumahan dan lahan juga akan diterjemahkan menjadi kenaikan kekayaan, dan karenanya menaikkan konsumsi. Secara umum, perubahan kebijakan moneter akan mempengaruhi harga perumahan dan lahan melalui sisi permintaan agregat. ${ }^{53}$

Fratantoni dan Schuh (2003) dan Owyang dan Wall (2004) mengkaji peran pasar perumahan regional di AS baik dari faktor permintaan maupun penawaran dalam menjelaskan variasi respon kebijakan moneter. Dari sisi permintaan, disparitas dalam sensitivitas regional terhadap perubahan suku bunga mortgage bisa mencerminkan perbedaan perilaku konsumsi, yang bisa ditunjukkan oleh sejumlah faktor seperti tingkat pekerjaan pemilik, ketersediaan ekuitas, dan prevalensi mortgage pembelian untuk disewakan kembali (buy-to-let mortgages). Sementara itu, faktor penawaran yang diidentifikasi mencakup perbedaan regional dalam ketersediaan lahan, peraturan pasar perumahan dan kedekatan dengan pusat kota.

\footnotetext{
50 Versi awal yang dipublikasikan membahas tentang Servizio di Studi (2000) dan C.E.P.R Discussion Paper (2000)

51 Istilah ini mengacu pada pasar properti sebagai 'barang lokal' dan karenanya tidak bergerak.

52 Bernanke dan Blinder (1992) menunjukkan bahwa ada strong inverse lead-lag relationship antara kebijakan moneter, sebagaimana diukur dari spread suku bunga federal fund atau spread suku bunga (Friedman dan Kuttner, 1993) dengan perumahan dan aktivitas riil lainnya.

53 Rincian lebih lanjut, lihat misalnya, Mishkin (1995, 1996).
} 
Sebagaimana terlihat dalam tabel, koefisien kontribusi sektor manufaktur dan konstruksi terhadap PDB pada dampak maksimal adalah sekitar -0,02. Rata-rata estimasi penurunan output setelah adanya kenaikan suku bunga sebesar satu persen adalah 0,769 (lihat Lampiran 1), jadi jika kontribusi sektor-sektor tersebut terhadap ekonomi naik satu persen, maka dampak output akan turun sekitar 2,60 persen. Dengan kata lain, daerah yang padat modal akan mengalami penurunan output lebih besar setelah adanya kenaikan suku bunga dibandingkan dengan daerah yang ekstensif modal.

Sementara itu, koefisien time-elapsed pada tingkat maksimal adalah sekitar 0,02. Dengan mengikuti interpretasi di atas, ini berarti jika kontribusi sektor manufaktur dan konstruksi terhadap ekonomi naik satu persen, maka time-speed untuk mencapai dampak penuh dari gonjangan moneter pada output akan lebih lama sekitar 0,22 hari (atau 5,28 jam).

Variabel finansial - Seperti dibahas sebelumnya, kami menggunakan beberapa ukuran yang mewakili struktur keuangan dan pembangunan sektor keuangan. Pada berbagai spesifikasi, hanya kontribusi kredit terhadap PDB (sebagai ukuran tingkat pembangunan sektor keuangan) yang secara meyakinkan terlihat positif (secara absolut) dan signifikan di hampir sebagian besar regresi. Hasil ini memperkuat fakta bahwa perbedaan regional dalam tingkat pembangunan sektor keuangan memainkan peran penting dalam perbedaan transmisi kebijakan moneter antar daerah sub-nasional. ${ }^{54}$

Landasan teoritis untuk menjelaskan hubungan antara pembangunan sektor keuangan dan variasi besaran dampak (effect size) bisa mengacu pada jalur kredit dari kebijakan moneter. Kebijakan moneter yang ketat berdampak negatif pada harga aset, dan nilai agunan, sehingga mempengaruhi kemampuan agen untuk meminjam. Kemudian, hambatan kredit semacam itu bisa menghambat permintaan agregat, dan karenanya berdampak negatif pada pertumbuhan output. Oleh sebab itu, daerah-daerah yang kekurangan modal, dan karenanya lebih bergantung pada sumber-sumber eksternal keuangan bank, cenderung lebih terkena dampak negatif jika suku bunga meningkat.

Disamping itu, tingkat aksesibilitas ke pendanaan eksternal juga mungkin berbeda-beda antar daerah. Daerah inti (core region) yang memiliki lebih banyak akses ke berbagai jenis pendanaan eksternal mungkin tidak terlalu terkena dampak perubahan suku bunga dibandingkan dengan daerah pinggiran (peripherial region). ${ }^{55}$ Oleh sebab itu, kami menggunakan kapitalisasi pasar saham sebagai ukuran kunci dari struktur keuangan dan karenanya bisa mewakili sumber

54 Pada tingkat nasional, sejumlah penulis menemukan bukti yang mendukung arti penting sektor perbankan bagi transmisi kebijakan moneter; Bernanke dan Gertler (1995) memaparkan tinjauan atas hal ini.'

55 Ridhwan et al (2008) juga telah membahas perbedaan aksesibilitas ke pendanaan eksternal antara dua jenis daerah secara lebih detail. 
pendanaan alternatif, namun hal ini tidak terkonfirmasi oleh hasil statistik. Jumlah kantor bank per 100.000 orang yang juga digunakan sebagai ukuran pembangunan sektor keuangan juga tidak signifikan dalam menentukan perbedaan regional dalam transmisi moneter. ${ }^{56}$

Sementara itu, model kuartal keenambelas yang memprediksi dampak jangka menengah secara mengejutkan tidak menunjukkan hasil signifikan, berkebalikan dari model dampak jangka pendek dan model dampak maksimal. Hasil ini bisa jadi mencerminkan perdebatan yang belum selesai mengenai apakah uang memiliki dampak riil dalam jangka pendek, dan netral dalam jangka panjang. ${ }^{57}$

Dari Tabel IV.1, koefisien kontribusi kredit terhadap PDB pada dampak maksimal adalah sekitar -0,008. Dengan melihat rata-rata dampak output adalah 0,769, maka tiap kenaikan kontribusi kredit sebesar satu persen, akan ada penurunan output sebesar 1,04 setelah adanya kenaikan suku bunga sebesar satu persen. Serupa dengan itu, koefisien time-elapsed pada maksimal adalah sekitar 0,014; ini menunjukkan bahwa time-speed untuk mencapai dampak maksimal dari gonjangan moneter akan lebih lama sekitar 0,15 hari (atau setara dengan 3,65 jam).

Besaran ekonomi (economic size) - Koefisien besaran ekonomi cenderung memperlihatkan hasil yang signifikan dan dengan tanda negatif (secara absolut) terutama pada model maksimal dan jangka menengah. Hasil semacam ini tidak ditemukan pada model jangka pendek. Tanda minus menunjukkan bahwa ekonomi kecil lebih terkena dampak negatif dari gonjangan (suku bunga) bersama dibandingkan dengan ekonomi besar. Beberapa alasan dibalik argumen ini bisa diuraikan sebagai berikut.

Pertama, untuk memperoleh keuntungan dari perdagangan global, negara ekonomi kecil bisa menyiapkan diri melalui spesialisasi pada industri-industri tertentu. Akibatnya, spesialisasi ini lebih rentan terkena dampak gonjangan moneter yang seragam (Kalemli-Ozcan et al., 2001). Sementara itu, dari sisi politik posisi tawar, negara ekonomi besar cenderung bisa mempengaruhi kebijakan ekonomi nasional, dan karenanya lebih sinkron dengan siklus usaha agregat, atau tidak terlalu simetri (Pons-Novell dan Tirado-Fabregat, 2006).

Kedua, negara ekonomi kecil biasanya menghadapi dampak gonjangan yang lebih besar (kerugian output) dibandingkan dengan negara ekonomi besar, terutama terkait dengan tingkat ketahanan mereka yang lebih rendah terhadap gonjangan. Ini bisa terjadi karena keterbatasan sistem ekonomi mereka atau mekanisme penyesuaian yang ada tidak berjalan dengan sempurna.

56 Hasil ini tidak ditampilkan, dan bisa disediakan jika ada permintaan kepada penulis.

57 Argumen ini bisa jadi terlalu awal atau mungkin terlalu sederhana. Karenanya, kami meninggalkan pembasahan ini untuk penelitian lebih lanjut. 
Keterbatasan semacam itu bisa terlihat dari tingkat akumulasi simpanan yang rendah, tidak adanya pengaturan kelembagaan, hambatan fiskal yang lebih besar, bottleneck penawaran dan ketergantungan yang lebih besar pada negara-negara lain (investasi asing). Sebaliknya, negara ekonomi besar cenderung memiliki modal yang lebih kuat dan mekanisme yang lebih fleksibel dalam menghadapi gonjangan.

Ketiga, dalam membahas tingkat regional versus nasional, Alesina et al. (2005) juga mendukung argumen ini dengan menyebutkan peran pembagian risiko antar daerah (interregional risk-sharing) dan transfer fiskal dengan daerah-daerah yang menghadapi goncangan yang tak berkaitan (imperfectly uncorrelated shocks): "... negara-negara besar lebih mampu memberikan jaminan pada daerah-daerah yang terkena dampak gonjangan bersama...", dan "...mereka bisa membangun skema distributif sedemikian rupa sehingga bisa menyalurkan sumber daya dari daerah kaya ke daerah miskin."

Dalam studinya, GS tidak bisa memperoleh hasil regresi signifikan untuk besaran ekonomi, jadi mereka berkesimpulan bahwa tidak ada perbedaan dampak output antara negara kecil dan besar. Di sisi lain, Ehrman (1998) mendeteksi heterogenitas yang substansial dalam besarnya respon kebijakan di negara-negara Eropa, dimana negara-negara kecil memiliki respon kecil sedangkan negara-negara besar memiliki respon besar. ${ }^{58}$

Koefisien besaran ekonomi pada dampak maksimal adalah sekitar 0,14. Dengan melihat rata-rata dampak output adalah 0,769; jika besaran suatu ekonomi naik satu persen dibandingkan ekonomi lain, maka dampak output setelah ada kenaikan suku bunga sebesar satu persen akan turun sekitar 18,21 persen. Dengan kata lain, semakin besar ekonomi, semakin sedikit kerugian output. Sementara itu, koefisien negatif dari time-elapsed pada maksimal menunjukkan bahwa semakin besar ekonomi, dampak gonjangan moneter akan lebih cepat dibandingkan pada ekonomi kecil.

Dengan menggabungkan dua temuan ini, kami bisa menyimpulkan bahwa ekonomi besar lebih baik dibandingkan dengan ekonomi kecil karena kerugian output lebih kecil. Akan tetapi, mereka akan menghadapi dampak penuh gonjangan dalam waktu lebih cepat daripada ekonomi kecil.

Derajat keterbukaan - Berdasarkan pada model regresi kami, kontribusi ekspor (dalam barang dan jasa) terhadap PDB kurang memiliki signifikansi statistik dalam menentukan perbedaan dampak kebijakan moneter baik dalam hal ukuran output maupun time-speed.

58 Meskipun, dia kemudian menyatakan bahwa dampak asimetris mungkin tidak berlanjut setelah negara-negara tersebut bergabung ke dalam EMU, karena peluang arbitrase baru menyebabkan adanya beberapa tingkat harmonisasi. 
Dengan menggunakan pendekatan serupa, Peersman dan Smets (2002) dan Dedola dan Lippi (2005) juga gagal menemukan bukti signifikan bahwa derajat keterbukaan adalah faktor yang bisa menjelaskan respon heterogen. Namun hasil ini mungkin disebabkan oleh kenyataan bahwa ukuran ini adalah pendekatan tidak langsung dalam menjelaskan derajat keterbukaan terutama di bidang moneter (keuangan). Karenanya, kita bisa mempertimbangkan jenis ukuran keterbukaan lain yang bisa secara langsung memperlihatkan transaksi keuangan lintas batas, dan karenanya akan lebih baik lagi dalam mengkaji kaitan antara derajat keterbukaan dengan gonjangan kebijakan moneter. ${ }^{59}$ Masalah ini bisa dijadikan bahasan penelitian lebih lanjut.

Titik tengah periode pengamatan Variabel ini hanya terlihat signifikan pada model kuartal keempat. Temuan ini menunjukkan bahwa dampak output dari kebijakan moneter cenderung melemah terutama dalam kurun waktu pengamatan studi kami (antara tahun 1970an dan 2000an).

Dengan menggunakan analisa grafis tersendiri60, kami juga menemukan bahwa ada kecenderungan pemendekan durasi waktu untuk mencapai dampak output maksimal dalam berbagai studi. Temuan ini cenderung konsisten dengan literatur yang ada dan fenomena sekarang ini. Peran koordinasi yang baik dalam pengelolaan moneter dan fiskal (seperti di area Euro) dan kemajuan teknologi karena cepatnya perkembangan Teknologi Informasi dan Komunikasi (ICT) merupakan faktor kunci dalam mempercepat ripple effect gonjangan moneter antar daerah dan benua.

Dalam hal karakteristik studi, Tabel IV. 1 menunjukkan bahwa jenis model yang digunakan (berdasarkan pada identifikasi dan batasan khusus) pada studi primer cenderung terlihat signifikan dalam menjelaskan heterogenitas antar studi terutama untuk varc dan vard. Fitur penting dari skema identifikasi pertama adalah bahwa berdasarkan model VAR struktural (SVAR) dengan batasan non-rekursif dan jangka panjang; ${ }^{61}$ batasan tersebut diklaim lebih teoritis dan bukan hanya sematata-mata bergantung pada data. ${ }^{62}$

59 Studi kami berfokus pada peran suku bunga sebagai jalur utama kebijakan moneter, sedangkan literatur yang ada juga menemukan bahwa jalur nilai tukar bisa memainkan peran kunci dalam menentukan variasi dampak kebijakan. Suku bunga yang tinggi mendorong masuknya modal, yang menyebabkan nilai tukar terapresiasi, dan kemudian menyebabkan hilangnya daya saing dan karenanya, menyebabkan penurunan permintaan ekspor. Dengan menggunakan dampak daya saing ini pada permintaan eksternal, terlihat bahwa daerah-daerah yang intensif mengekspor akan lebih sensitif terhadap perubahan kebijakan moneter. Karenanya, diperlukan penelitian lebih lanjut untuk melihat apakah jalur nilai tukar bisa melihat dampak eksternal ini.

60 Demi keringkasan, grafik tidak ditampilkan

61 Ehrmann (2000) menyatakan bahwa SVAR memiliki keunggulan kongruensi (congruency advantage), yakni kesesuaian model dengan semua bukti yang ada dari berbagai sumber. Ini memungkinkan SVAR untuk memiliki pola sistematis bebas dalam error term dan bisa membentuk model yang baik.

62 Struktur non-rekursif ditujukan untuk mengetahui non-contemporaneous effect dari gonjangan moneter. Sebagai pertimbangan praktis, untuk mengetahui dampak inovasi suku bunga pada output, kita harus meletakkan output setelah suku bunga; karenanya kebijakan moneter tidak bisa merespon output seketika itu juga (keterangan lebih lanjut, lihat Enders, 2004). 
Batasan yang kedua memungkinkan adanya kointegrasi, dan karenanya bisa ditentukan sebagai model vector error correction. Hal ini juga memberikan informasi tentang hubungan jangka panjang antar variabel. Patut dicatat bahwa selain kointegrasi, harus ada pula interpretasi ekonomi. Jika tidak, penggunaan hubungan kointegrasi yang tidak tepat bisa menyebabkan estimasi yang bias (Ramaswamy dan Slok, 1998).

Meskipun batasan-batasan lain tidak signifikan, namun menurut pemahaman kami tidak ada standar kriteria yang bisa menentukan skema identifikasi mana yang lebih bagus dibandingkan yang lain, karena berbagai studi berbeda memiliki pendekatan dan alasan ekonomi yang berbeda-beda pula. Untuk lebih memahami masalah ini, diperlukan studi lebih lanjut, namun hal ini berada di luar ruang lingkup makalah ini.

Regional dummy yang digunakan untuk melihat karakteristik spesifik daerah juga terlihat signifikan. Karenanya, ini cukup konsisten dengan kepercayaan umum, karena dampak asimetris dari kebijakan makroekonomi cenderung lebih terlihat jelas dalam satu negara dibandingkan antar negara, seperti di Eropa.

Selain itu, variasi pada data frekuensi waktu juga bisa melihat perbedaan studi tersebut. Signifikansi data kuartal dibandingkan data bulanan bisa menunjukkan bahwa ada hubungan yang lebih kuat antara perubahan suku bunga dengan PDB (data berbasis kuartal) dibandingkan dengan data bulanan seperti indeks produksi industri. Hal ini masuk akal mengingat bahwa indikator pertama mencakup aktivitas ekonomi dalam ruang lingkup yang lebih besar baik dalam hal produksi maupun permintaan; sementara indikator kedua hanya berisi indikator produksi.

\section{IV.3. Pemeriksaan Robustness}

Untuk memeriksa robustness dan keandalan hasil meta-regresi, kami menghitung ulang hasil dari Tabel IV.1 (sebagai benchmark) dengan menggunakan beberapa skema pembobotan sebagaimana telah dibahas pada Bagian IV.1 Robustness dari hasil regresi bisa ditunjukkan oleh konsistensi koefisien pada berbagai spesifikasi berbeda.

Untuk melihat kualitas studi, kami menggunakan peringkat jurnal sebagai bobot sebagaimana terlihat pada Tabel IV.2. Nampaknya hasil dari empat ukuran dampak masih tak berubah dibandingkan dengan regresi benchmark dalam hal tanda, signifikansi dan ukuran. Secara khusus, semua variabel penjelas utama seperti intensitas modal, pembangunan sektor keuangan, besaran ekonomi, periode waktu, dan tipe batasan adalah signifikan. Penggunaan bobot alternatif terkait dengan derajat kebebasan dan ukuran sampel tidak secara kuat mempengaruhi hasil awal. Karenanya dengan melihat semua temuan ini, kami berkesimpulan bahwa regresi benchmark cenderung robust. 


\begin{tabular}{|c|c|c|c|c|}
\hline \multicolumn{5}{|c|}{$\begin{array}{c}\text { Tabel IV.2 } \\
\text { Skema pembobotan berbeda (1) }\end{array}$} \\
\hline \multirow{2}{*}{$\begin{array}{l}\text { Dependent } \\
\text { variables }\end{array}$} & \multirow[b]{2}{*}{ Independent variables } & \multicolumn{3}{|c|}{ Weighted } \\
\hline & & journal-rank & $\begin{array}{l}\text { degrees of } \\
\text { freedom }\end{array}$ & $\begin{array}{l}\text { sample } \\
\text { size }\end{array}$ \\
\hline 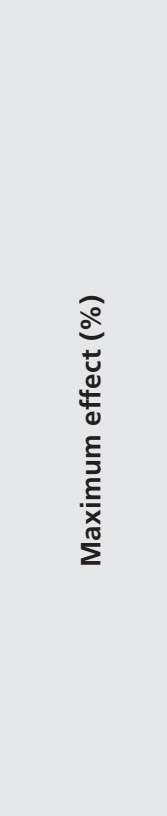 & $\begin{array}{l}\text { Share of manufacturing and } \\
\text { construction sector to GDP (\%) } \\
\text { Share of credit to GDP (\%) } \\
\text { Size of GDP } \\
\text { Share of export to GDP (\%) } \\
\text { Regional dummy } \\
\text { Mid-point of observation period } \\
\text { (in quarters) } \\
\text { Restriction type (vara) } \\
\text { Restriction type (varb) } \\
\text { Restriction type (varc) } \\
\text { Restriction type (vard) } \\
\text { Quarterly data } \\
\text { Constant }\end{array}$ & $\begin{array}{r}-0.009 \\
(-1.20) \\
-0.00879^{* *} \\
(-3.35) \\
0.109^{* *} \\
(2.68) \\
0.00404 \\
(1.17) \\
-0.361 \\
(-0.85) \\
0.164^{*} \\
(2.45) \\
-0.0994 \\
(-0.67) \\
-0.0854 \\
(-0.25) \\
-0.631 * * * \\
(-4.16) \\
-0.204 \\
(-1.33) \\
0.430^{* *} \\
(2.61) \\
-2.086^{*} \\
(-2.51)\end{array}$ & $\begin{array}{r}-0.0155^{*} \\
(-1.99) \\
-0.00536 \\
(-1.63) \\
0.112^{*} \\
(2.50) \\
0.00146 \\
(0.34) \\
-0.567 \\
(-1.58) \\
0.103 \\
(1.19) \\
0.137 \\
(0.81) \\
0.0156 \\
(0.07) \\
-0.547 * * \\
(-2.77) \\
-0.0807 \\
(-0.41) \\
0.222 \\
(1.18) \\
-1.952^{*} \\
(-2.09)\end{array}$ & $\begin{array}{r}-0.002 \\
(-0.21) \\
-0.00707^{*} \\
(-2.53) \\
0.103^{*} \\
(2.15) \\
-0.000198 \\
(-0.05) \\
-0.547 \\
(-1.76) \\
0.0296 \\
(0.41) \\
0.21 \\
(1.49) \\
0.388^{*} \\
(2.09) \\
-0.365^{*} \\
(-2.07) \\
0.0324 \\
(0.16) \\
0.191 \\
(1.25) \\
-2.210^{*} \\
(-2.19)\end{array}$ \\
\hline 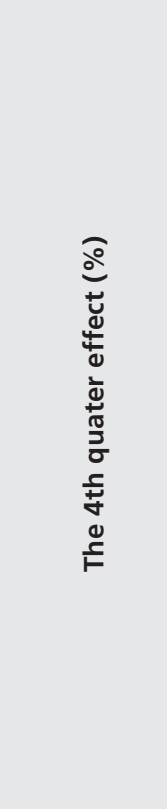 & $\begin{array}{l}\text { Share of manufacturing and } \\
\text { construction sector to GDP (\%) } \\
\text { Share of credit to GDP (\%) } \\
\text { Size of GDP } \\
\text { Share of export to GDP (\%) } \\
\text { Regional dummy } \\
\text { Mid-point of observation period } \\
\text { (in quarters) } \\
\text { Restriction type (vara) } \\
\text { Restriction type (varb) } \\
\text { Restriction type (varc) } \\
\text { Restriction type (vard) } \\
\text { Quarterly data } \\
\text { Constant }\end{array}$ & $\begin{array}{r}-0,0114^{*} \\
(-2,50) \\
-0,00408^{*} \\
(-2,60) \\
-0,0161 \\
(-0,66) \\
-0,00141 \\
(-0,69) \\
-0,181 \\
(-0,72) \\
0,177^{* * *} \\
(4,45) \\
-0,0705 \\
(-0,87) \\
-0,109 \\
(-0,54) \\
-0,278^{* *} \\
(-3,12) \\
-0,368^{* * *} \\
(-3,97) \\
-0,0258 \\
(-0,26) \\
0,94 \\
(1,89)\end{array}$ & $\begin{array}{r}-0,0138^{* *} \\
(-3,23) \\
-0,00259 \\
(-1,46) \\
-0,00824 \\
(-0,34) \\
-0,000821 \\
(-0,36) \\
-0,406^{*} \\
(-2,07) \\
0,134^{* *} \\
(2,81) \\
0,0152 \\
(0,18) \\
0,116 \\
(1,00) \\
-0,268^{* *} \\
(-2,61) \\
-0,331 * * \\
(-3,14) \\
0,172 \\
(1,66) \\
0,529 \\
(1,04)\end{array}$ & $\begin{array}{r}-0,0108^{*} \\
(-2,22) \\
-0,00361^{*} \\
(-2,12) \\
-0,00653 \\
(-0,23) \\
-0,00286 \\
(-1,19) \\
-0,421^{*} \\
(-2,21) \\
0,107^{*} \\
(2,40) \\
0,0483 \\
(0,62) \\
0,133 \\
(1,20) \\
-0,286^{* *} \\
(-2,75) \\
-0,281^{*} \\
(-2,28) \\
0,0745 \\
(0,80) \\
0,6 \\
(0,98)\end{array}$ \\
\hline
\end{tabular}




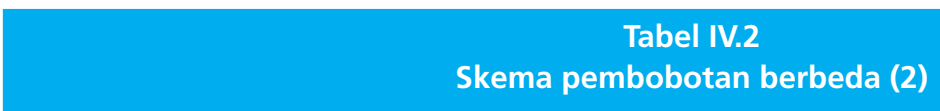

\begin{tabular}{|c|c|c|c|c|}
\hline \multirow{2}{*}{$\begin{array}{c}\text { Dependent } \\
\text { variables }\end{array}$} & \multirow[b]{2}{*}{ Independent variables } & \multicolumn{3}{|c|}{ Weighted } \\
\hline & & journal-rank & $\begin{array}{l}\text { degrees of } \\
\text { freedom }\end{array}$ & $\begin{array}{l}\text { sample } \\
\text { size }\end{array}$ \\
\hline 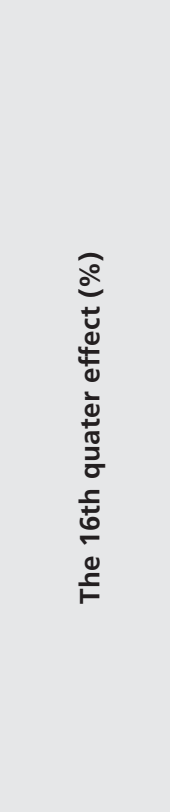 & $\begin{array}{l}\text { Share of manufacturing and } \\
\text { construction sector to GDP (\%) } \\
\text { Share of credit to GDP (\%) } \\
\text { Size of GDP } \\
\text { Share of export to GDP (\%) } \\
\text { Regional dummy } \\
\text { Mid-point of observation period } \\
\text { (in quarters) } \\
\text { Restriction type (vara) } \\
\text { Restriction type (varb) } \\
\text { Restriction type (varc) } \\
\text { Restriction type (vard) } \\
\text { Quarterly data } \\
\text { Constant }\end{array}$ & $\begin{array}{r}-0.0181^{*} \\
(-2.26) \\
-0.00630^{*} \\
(-2.29) \\
0.115^{*} \\
(2.72) \\
0.00612 \\
(1.72) \\
-0.0572 \\
(-0.12) \\
0.137^{*} \\
(1.98) \\
-0.301 * \\
(-2.13) \\
-0.378 \\
(-0.96) \\
-0.243 \\
(-1.56) \\
0.323^{*} \\
(2.01) \\
-0.0648 \\
(-0.38) \\
-1.404 \\
(-1.62)\end{array}$ & $\begin{array}{r}-0.0234^{* *} \\
(-3.34) \\
-0.00511 \\
(-1.72) \\
0.134^{* * *} \\
(3.36) \\
0.00271 \\
(0.71) \\
-0.405 \\
(-1.23) \\
0.089 \\
(1.15) \\
0.0444 \\
(0.32) \\
-0.233 \\
(-1.20) \\
-0.115 \\
(-0.68) \\
0.480 * * \\
(2.80) \\
-0.0943 \\
(-0.55) \\
-1.607 \\
(-1.94)\end{array}$ & $\begin{array}{r}-0.013 \\
(-1.59) \\
-0.00186 \\
(-0.64) \\
0.0331 \\
(0.70) \\
0.00367 \\
(0.90) \\
0.0706 \\
(0.21) \\
0.0716 \\
(0.98) \\
-0.094 \\
(-0.74) \\
-0.0045 \\
(-0.02) \\
-0.152 \\
(-0.87) \\
0.501 * \\
(2.50) \\
-0.294 \\
(-1.88) \\
-0.262 \\
(-0.26)\end{array}$ \\
\hline 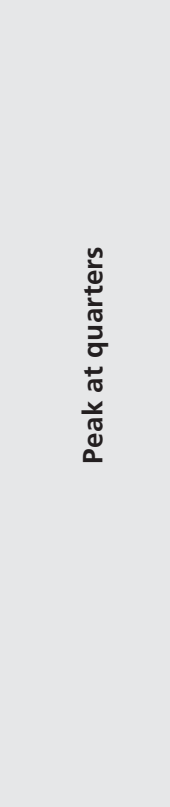 & $\begin{array}{l}\text { Share of manufacturing and } \\
\text { construction sector to GDP (\%) } \\
\text { Share of credit to GDP (\%) } \\
\text { Size of GDP } \\
\text { Share of export to GDP (\%) } \\
\text { Regional dummy } \\
\text { Mid-point of observation period } \\
\text { (in quarters) } \\
\text { Restriction type (vara) } \\
\text { Restriction type (varb) } \\
\text { Restriction type (varc) } \\
\text { Restriction type (vard) } \\
\text { Quarterly data } \\
\text { Constant }\end{array}$ & $\begin{array}{r}0.013 \\
(1.53) \\
0.0147 * * * \\
(5.08) \\
-0.118^{* *} \\
(-2.62) \\
-0.00236 \\
(-0.62) \\
0.581 \\
(1.25) \\
0.00154 \\
(0.02) \\
0.142 \\
(0.86) \\
0.437 \\
(1.17) \\
0.0336 \\
(0.20) \\
-0.650 * * * \\
(-3.85) \\
1.187 * * * \\
(6.53) \\
1.378 \\
(1.50)\end{array}$ & $\begin{array}{r}0.0164^{*} \\
(2.29) \\
0.0140^{* * *} \\
(4.66) \\
-0.0896^{*} \\
(-2.19) \\
-0.000823 \\
(-0.21) \\
0.663^{*} \\
(2.01) \\
-0.0558 \\
(-0.70) \\
0.0531 \\
(0.34) \\
0.407^{*} \\
(2.02) \\
-0.121 \\
(-0.67) \\
-0.734^{* * *} \\
(-4.08) \\
0.970 * * * \\
(5.60) \\
1.017 \\
(1.18)\end{array}$ & $\begin{array}{r}0.0220 * \\
(2.32) \\
0.0144^{* * *} \\
(4.34) \\
-0.0653 \\
(-1.15) \\
-0.00517 \\
(-1.10) \\
0.697 \\
(1.88) \\
-0.00433 \\
(-0.05) \\
-0.113 \\
(-0.67) \\
0.32 \\
(1.45) \\
-0.235 \\
(-1.13) \\
-0.779 * * \\
(-3.31) \\
0.868 * * * \\
(4.79) \\
0.524 \\
(0.44)\end{array}$ \\
\hline
\end{tabular}




\section{IV.4. Trajektori Output}

Hasil dari meta-analisis bisa digunakan untuk membuat trajektori untuk berbagai tipe negara atau daerah (lihat Grafik IV.6). Kami mendapatkan pola respon berbentuk menonjol (hump-shaped).

Nampaknya besaran dan waktu dampak cenderung lebih besar dan lebih panjang di negara-negara bagian AS dibandingkan di negara-negara Eropa. Ini bisa menjadi indikasi bahwa kebijakan moneter AS cenderung lebih sensitif terhadap perubahan kebijakan moneter dibandingkan zona Eropa. Meskipun pembahasan sebelumnya memaparkan transmisi moneter dari permintaan agregat, namun perbedaan dampak kebijakan moneter juga bisa diakibatkan oleh perbedaan dalam kurva penawaran. OECD (1999) mengungkapkan bahwa perbedaan regional dalam hal fleksibilitas dan fitur kelembagaan pasar produk dan tenaga kerja juga bisa mengakibatkan perbedaan dampak. Selain itu, De Grauwe dan Storti (2004) baru-baru ini juga menyatakan bahwa perbedaan sensitivitas antara dua zona moneter bisa disebabkan oleh perbedaan rigiditas penawaran yang cenderung lebih rigid di UE dibandingkan di AS.

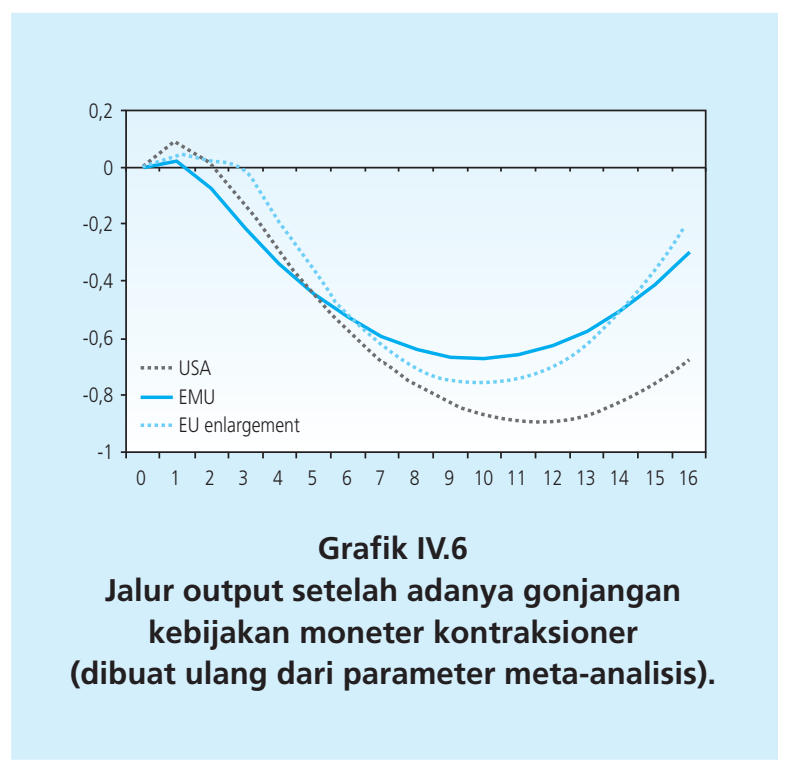

Selanjutnya, kami akan membahas besaran dan waktu dampak moneter dari masingmasing daerah sebagai berikut. Untuk tiap kenaikan suku bunga sebesar satu persen poin, rata-rata besaran dampak setelah empat kuartal adalah antara -0,16 sampai -0,30 persen dari baseline, sedangkan setelah enam belas kuartal, besaran dampak pada output riil adalah antara 
-0,13 sampai -0,68 persen. Kemudian, dampak maksimal berkisar antara -0,56 sampai 0,87 persen, dan terjadi antara kuartal 3-11 setelah gonjangan. ${ }^{63}$

Dari sudut pandang geografis, dampak maksimal gonjangan di negara-negara Uni Eropa (UE) bagia barat $(-0,59)$ cenderung lebih rendah dibandingkan di bagian timur $(-0,72$ persen). Waktu untuk mencapai dampak tertinggi lebih lama di barat dibandingkan di timur. ${ }^{64}$ Hasil ini nampaknya mendukung temuan ekonometrik sebelumnya bahwa negara ekonomi kecil (timur) menghadapi kerugian output yang lebih besar daripada negara di barat, sedangkan untuk pola waktu yang terjadi adalah kebalikannya. Dua pola ini sangat mengingatkan kita pada fenomena core-periphery yang dibedakan dalam literatur tentang gonjangan asimetris. ${ }^{65}$

\section{KESIMPULAN}

Pada makalah ini kami menemukan fakta-fakta berdasarkan pada meta-analisis tentang dampak riil dari kebijakan moneter pada tingkat regional, terutama di AS dan Eropa. Hasil meta-analisis kami mengungkapkan secara meyakinkan tentang arti penting intensitas modal (komposisi struktural) dan kredit (pembangunan sektor keuangan) yang memainkan peran penting bagi pembangunan regional.

Selain itu, meskipun tidak ada keyakinan sebelumnya tentang bagaimana dampak gonjangan moneter yang berbeda berkaitan dengan besaran ekonomi, tapi disini terlihat secara cukup meyakinkan bahwa negara ekonomi kecil mengalami kerugian output yang lebih besar sebagai respon atas kontraksi ekonomi dibandingkan dengan negara ekonomi besar. Karenanya, fenomena ini menunjukkan pola core-periphery antar negara-negara Eropa. ${ }^{66}$

Disamping itu, karena kebijakan moneter diambil secara seragam pada tingkat nasional, sementara pada saat yang sama potensi implikasi distribusional juga bisa muncul antar daerah, maka masih relevan untuk menanyakan apa yang bisa dilakukan oleh kebijakan moneter bagi pembangunan ekonomi (regional), karena kebijakan moneter yang kredibel bisa melakukan lebih banyak dari sekedar menentukan suku bunga untuk mencapai target inflasi nasional.

63 Seperti terlihat pada Grafik IV.6 terutama untuk negara-negara UE bisa dibagi menjadi EMU (eurozone) dan perluasan UE. Kelompok perluasan UE terdiri dari negara-negara tambahan yakni negara-negara Eropa Tengah dan Timur dan negara-negara UE yang memiliki rezim nilai tukar mengambang bebas (untuk keterangan lebih lanjut, lihat: www.ecb.int; http://ec.europa.eu/index_en.htm). Selain itu pengaturan nilai tukar mereka bersandar pada suku bunga di area euro, dan sejalan dengan waktu cenderung sama dengan suku bunga euro.

64 Besaran dampak setelah empat kuartal dan enam belas kuartal antar dua daerah kurang lebih sama.

65 Sebelumnya Artis and Zhang (1998a, 1998b) telah menunjukkan bahwa ada kecenderungan pola core-periphery antar negaranegara Eropa.

66 Hallett and Piscitelli (1999) membahas secara lengkap tentang dampak asimetris berdasarkan atas perbedaan transmisi moneter, transmisi gaji/harga dan kepemilikan aset sektor swasta. 
Berdasarkan pada temuan di sini, kami berpandangan bahwa proses pembuatan kebijakan nasional terutama untuk prediksi (inflasi) ekonomi serta dampak kebijakan ${ }^{67}$ bisa ditingkatkan dengan mempertimbangkan perbedaan dampak pada aktivitas regional. Serupa dengan itu, Aksoy et al. (2002) berpandangan bahwa penggunaan pemungutan suara mayoritas oleh ECB dalam menyusun kebijakan bersama bisa membawa potensi konflik yang signifikan antar negara anggota dalam lingkungan yang dikarakterisasikan dengan gonjangan asimetris, dan karenanya mereka mengajukan aturan keputusan dimana konsensus memainkan peran yang lebih besar. Secara implisit hal ini memberikan keseimbangan kekuasaan yang lebih besar dengan melihat perbedaan karakteristik antar negara atau daerah. Untuk itu, masalah tentang bagaimana kebijakan moneter yang efektif harus dilakukan baik di tingkat meso (regional) maupun mikro (perusahaan, rumah tangga, dll.) perlu diteliti lebih lanjut. 


\section{DAFTAR PUSTAKA}

Abreu, M., de Groot, H.L.F. and Florax, R.J.G.M. (2005) A meta-analysis of -convergence: the legendary 2\%. Journal of Economic Surveys 19, 389-420.

Altavilla, C. (2000) Measuring monetary policy asymmetries across EMU countries. Katholieke Universiteit Leuven, Discussion Paper no. 22.

Anzuini, A. and Levy, A. (2007) Monetary policy shocks in the new EU members: A VAR approach. Applied Economics 39, 9, 1147-1162.

Alesina, A., Spolaore, E. and Wacziarg, R. (2005) Trade, growth and the size of countries. In: Aghion, P. and Durlauf, S. (eds), Handbook of Economic Growth. North Holland: Elsevier. Aksoy, Y., De Grauwe, P., and Dewachter, H. (2002) Do asymmetries matter for European monetary Policy? European Economic Review 46, 443-469.

Artis M.J. and Zhang, W. (1998a) Core and periphery in EMU: a cluster analysis. European University Institute, RSC Working Papers no. 98/37.

Artis M.J. and Zhang, W. (1998b) Membership of EMU: a fuzzy clustering analysis of alternative criteria. European University Institute, RSC Working Papers no. 98/52.

Baldwin, R.E. and Wyplosz, C. (2004) The Economics of European Integration. New York: McGraw-Hill.

Barth III, M. J. and. Ramey, V. A. (2001) The cost channel of monetary transmission. NBER Macroeconomics Annual 16, 199-240.

Beck, T., Levine, R. and Loayza, N. (2000) Financial intermediation and growth: Causality and causes. Journal of Monetary Economics 46, 1, 31-77.

Bernanke, B. S. and Blinder, A. S. (1992) The federal funds rate and the channels of monetary transmission. The American Economic Review 82, 4, 901-21.

Bernanke, B.S. (1986) Altenative explanations of money-income correlation.

Carnegie-Rochester Conference Series on Public Policy 25, 49-100.

Bernanke, B.S. and Gertler, M. (1995) Inside the black box, the credit channel of monetary policy transmission. Journal of Economic Perspectives 9, 27-48.

Blanchard, O. J. and D. Quah. (1989) The dynamic effects of aggregate demand and supply disturbances. The American Economic Review 79, 4, 655-73.

Bösch, H. (2004). Reanalyzing a meta-analysis on extra-sensory perception dating from 1940, the first comprehensive meta-analysis in the history of science. In S. Schmidt (Ed.), Proceedings of the 47th Annual Convention of the Parapsychological Association, University of Vienna, (pp. 1-13) 
Card, D. and Krueger, A. B. (1995) Time-series minimum-wage studies: a meta-analysis. The American Economic Review 85, 238-43.

Carlino, G. and De Fina, R.H. (1998) The differential regional effects of monetary policy. Review of Economics and Statistics 80, 572-587.

Carlino, G. and De Fina, R.H. (1999) The differential regional effects of monetary policy: evidence from the U.S. States. Journal of Regional Science 39, 339-358.

Cecchetti, S. G. (1999) Legal structure, financial structure, and the monetary policy transmission mechanism. National Bureau of Economic Research, Working Paper no.-7151.

Clements, B.,-Kontolemis, Z., Levy, J., and Joaquim, V. (2001) Monetary Policy under EMU: Differences in the transmission mechanism. IMF, Working Paper no. 01/102.

Cover, J.P. (1992) Asymmetric effects of positive and negative money-supply shocks. The Quarterly Journal of Economics 107, 4, 1261-1282.

Dedola, L. and Lippi, F. (2005) The monetary transmission mechanism: Evidence from the industries of five OECD countries. European Economic Review 49, 1543-69.

De Grauwe, P. (1994)

The Economics of Monetary Integration. Oxford: Oxford University Press.

De Grauwe, P. and Storti, C. C. (2004) The effects of monetary policy: a meta-analysis CESIFO, Working Paper no. 1224.

De Long, J. B., Summers, L. H., Mankiw, N. G. and Romer, C. D. (1988) How Does Macroeconomic Policy Affect Output? Brookings Papers on Economic Activity 2, 433-494.

Ehrmann, M. (1998) Will EMU generate asymmetry? Comparing monetary policy transmission across European countries. EUI, Working Paper no.28.

Elbourne, A. and de Haan, J. (2004) Asymmetric Monetary Transmission in EMU: The Robustness

of VAR Conclusions and Cecchetti's Legal Family Theory. CESIFO, Working Paper no. 1327. Enders, W. (2004).

Applied Econometrics Time Series. Hoboken, NJ: John Wiley and Sons.

Faust, J. (1998) The robustness of identified VAR conclusions about money. Carnegie-Rochester Conference Series on Public Policy 49, 207-244.

Fishkind, H.H. (1977) The regional impact of monetary policy: an economic simulation study of Indiana (1958-1973). Journal of Regional Science 17, 77-88.

Florax, R. J. G. M., Groot, H. L. F. and Mooij, R. A. (2002) Meta-analysis: a tool for upgrading inputs of macroeconomic policy models. Tinbergen Institute, Discussion Papers no. 041/3. Florio (2004) The asymmetric effects of monetary policy.

Journal of Economic Surveys 18, 3, 409-426.

Frantantoni, M. and Schuh, S. (2003) Monetary policy, housing, and heterogeneous regional markets. 
Journal of Money, Credit and Banking 35, 557-589.

Ganley, J., and Salmon, C. (1997) The industrial impact of monetary policy shocks: some stylised facts. Bank of England, Working Paper no. 68.

Gali, J. (1992) How well does the IS-LM model fit postwar US data? The Quarterly Journal of Economics, 107, 2, 709-38.

Gali, J. (1999) Technology, employment, and the business cycle: do technology shocks explain aggregate fluctuations?

American Economic Review 89, 1, 249-71.

Garrison, C.B. and Chang, H.S. (1979) The effect of monetary and fiscal policies on regional business cycles. International Regional Science Review 4, 167-180.

Gerlach, S. and Smets, F. (1995) The monetary transmission mechanism: evidence from the G7 countries. BIS, Working Paper no. 26.

Gorg, H. and Strobl, E. (2001) Multinational companies and productivity spillovers: a metaanalysis. Economic Journal 111, 475, 723-39.

Greene, W. H. (2000) Econometric Analysis. New Jersey: Prentice Hall Upper Saddle River.

Guiso, L., Kashyap, A.K., Panetta, F. and Terlizzese, D. (2000) Will a common European monetary policy have asymmetric effects? Economic Perspectives 4, 56-75.

Gujarati, D. N. (2003) Basic Econometrics. New York: McGraw-Hill.

Hallet, A.H. and Piscitelli, L. (1999) EMU in reality: The effect of a common monetary policy on economies with different transmission mechanisms. Empirica 26, 4, 337-358.

Homes, M.J. (2000) Monetary shocks and the asymmetric adjustment of UK regional output. Environment and Planning C: Government and Policy 18, 667-680.

Karras, G. (1996) Are the output effects of monetary policy asymmetric? Evidence from a sample of European countries. Oxford Bulletin of Economics and Statistics 58, 2, 267-278.

Keef, S.P. and Roberts, L.A. (2004). The meta-analysis of partial effect sizes. British Journal of Mathematical and Statistical Psychology 57, 1, 97-129.

Kalaitzidakis, P., Mamuneas, T. P. and Stengos, T. (2003) Rankings of academic journals and institutions in economics. Journal of the European Economic Association 1, 6, 1346-66.

Kennedy, P. (2008) A Guide to Econometrics. Oxford: Blackwell Publishing,.

Kieler, M., and Saarenheimo, T. (1998). Differences in monetary policy transmission?: a case not closed. European Commission Economic Papers 2, 407.

King, R. G ., Plosser, C.I., Stock, J.H., and Watson, M.W. (1991) Stochastic trends and economic fluctuations. The American Economic Review 81, 4, 819-40.

King, R. G. and Levine, R. (1993) Finance and growth: Schumpeter might be right. The Quarterly Journal of Economics 108, 3, 717-37. 
Kiviet, B., Elbourne, A. and de Haan, J. (2003) Financial structure and monetary policy transmission in transition countries. Rijksuniversiteit Groningen Working Paper.

Knell, M., and Stix, H. (2003) The Income Elasticity of Money Demand: A Meta-analysis of Empirical Results. Journal of Economic Surveys 19, 3, 513-33.

Koetse, M. J., Florax, R. J. G. M. and de Groot, H. L. F. (2005) Correcting for primary study misspecifications in meta-analysis. Tinbergen Institute, Discussion Papers no. 05/029.

Krueger, A. B. (2003) Economic considerations and class size. Economic Journal 113, 34-63. Leeper, E. M., Sims, C.A., and Zha, T. (1996) What does monetary policy do? Brookings Papers on Economic Activity 2, 1-63.

Levine, R. (1997) Financial development and economic growth: Views and agenda. Journal of Economic Literature 35, 688-726.

Mankiw, N.G. (1997)-Macroeconomics. New York: Worth Publishers.

Mihov, I. (2001) One monetary policy in EMU. Economic Policy, 33, 369-406.

Miller, R.J. (1978) The Regional Impact of Monetary Policy in the United States. Lexington, MA: Lexington Books.

Mishkin, F. (1995) Symposium on the Monetary Transmission Mechanism. Journal of Economic Perspectives 9, 3-10.

Mishkin, F. S. (1996) The channels of monetary transmission: lessons for monetary policy. National Bureau of Economic Research, Working Paper no. 5464.

Mojon, B., and Peersman, G. (2001) A VAR description of the effects of monetary policy in the individual countries of the euro area. European Central Bank, Working Paper no. 92.

Nijkamp, P. and Poot, J. (2004) Meta-analysis of the effect of fiscal policies on long-run growth. European Journal of Political Economy 20, 1, 91-124.

Organisation for Economic Cooperation and Development (1999) EMU, Facts, Challenges and Policies. Paris: OECD.

Owyang, M.T. and Wall, H.J. (2004) Structural breaks and regional disparities in the transmission of monetary policy. Federal Reserve Bank of St. Louis, Working Paper no. 2003-008C.

Pearson, Karl, (1904), Mathematical contributions to the theory of evolution.

Peersman, G. (2004) The transmission of monetary policy in the Euro Area: are the effects different across countries? Oxford Bulletin of Economics and Statistics 66, 3, 285-308.

Pitzel, D., and Uuskula, L. (2005) The effect of financial depth on monetary transmission. Eesti Bank, Working Papers no. 10.

Ridhwan, M. M., Nijkamp P., Rietveld, P. and de Groot, H. L. F. (2008) Regional development and monetary policy: a review of the role of monetary unions, capital mobility and locational effects. VU Amsterdam, Research Memoranda no. 0007. 
Rose, A. K. and T. D. Stanley. (2005) A meta-analysis of the effect of common currencies on international trade. Journal of Economic Surveys 19,3, 347-65.

Romer, D. (1996). Advanced Macroeconomics. New York: McGraw-Hill Companies-Inc.

Schunk, D. (2005) The differential impacts of monetary policy: are the differences diminishing? Papers in Regional Science 84, 1, 127-36.

Shapiro, M. D. and Watson, M. W. (1988) Sources of business cycle fluctuations. NBER Macroeconomic Annual 3, 111-48.

Sims, C.A. (1980) Macroeconomics and reality. Econometrica 48, 1-48.

Sims, C.A. (1986) Are forecasting models usable for policy analysis.

Federal Reserve Bank of Minneapolis Quarterly Review (Winter edition), 3-16.

Smith, V. K. and J. C. Huang. (1995) Can markets value air quality? A meta-analysis of hedonic property value models. Journal of Political Economy 103, 209-27.

Stanley, T. D. (2005) Beyond publication bias. Journal of Economic Surveys 19, 3, 309-45.

Stanley, T. D. and Jarrell, S.B. (1989) Meta-Regression Analysis: a Quantitative Method of Literature Surveys.

Journal of Economic Surveys 19, 3, 299-308.

Sutton, A.J., Abrams, K.R., Jones, D.R., Sheldon, T.A. and Song, F. (2000) Methods for MetaAnalysis in Medical Research. Chichester: John Wiley \& Sons.

Taylor, J. (1995) The monetary transmission mechanism: an empirical framework. Journal of Economic Perspectives 9, 11-26.

Weichselbaumer, D. and R. Winter-Ebmer. (2005) A meta-analysis of the international wage gender gap. Journal of Economic Surveys 19, 3, 479-511.

White, H. (1984) Asymptotic Theory for Econometricians. Orlando: Academic Press. 


\begin{tabular}{|c|c|c|c|c|c|c|}
\hline \multicolumn{7}{|c|}{$\begin{array}{c}\text { Lampiran IV.1 } \\
\text { Statistik deskriptif tentang semua calon variabel yang digunakan dalam regresi meta-analisis }\end{array}$} \\
\hline & Variable & Obs & Mean & Std. Dev & Min & Max \\
\hline 1. & $\begin{array}{l}\text { Dependent variables } \\
\text { Output effect of monetary shock in the 4th quarter (short-run effect) } \\
\text { Output effect of monetary shock in the 16th quarter (medium-run effect) } \\
\text { Output effect of monetary shock at the maximum level (maximum effect) } \\
\text { Time-elapsed at the maximum effect }\end{array}$ & $\begin{array}{l}185 \\
179 \\
171 \\
170\end{array}$ & $\begin{array}{c}-0.3108 \\
-0.4967 \\
-0.7687 \\
8.2763\end{array}$ & $\begin{array}{l}0.3693 \\
0.6216 \\
0.6377 \\
4.4882\end{array}$ & $\begin{array}{c}-1.8750 \\
-2.8650 \\
-2.9400 \\
0.3330\end{array}$ & $\begin{array}{c}1.6190 \\
0.6860 \\
0.0300 \\
20.0000\end{array}$ \\
\hline 2. & $\begin{array}{l}\text { Restriction type and data characateristics } \\
\text { Dummy for identification and restriction scheme } \\
\text { - VAR -Choleski decomposition and recursive (Sims, 1980) } \\
\text { - Structural VAR with non recursive contemporaneous restriction } \\
\text { Bernanke-Blinder, 1992) } \\
\text { - Structural VAR with long-run restricitions (Blanchard and Quah, 1989) } \\
\text { - Combination of short-run and long-run restrictions (Gali, 1992, 1999) } \\
\text { - VAR with cointegration factor (King et al., 1991) } \\
\text { Dummy for model dimension: } \\
\text { - Basic form (four variables: price, output, interest rate and } \\
\text { money supply/credit) } \\
\text { - Basic form with exchange rate added } \\
\text { - Basic form with exchange rate, commodity price and foreign } \\
\text { interest rate added } \\
\text { Dummy output variable : } \\
\text { - GRDP (gross regional domestic products) or GDP } \\
\text { - total personal income } \\
\text { - Industrial production index } \\
\text { Number of degrees of freedom } \\
\text { Sample size } \\
\text { Journal rank } \\
\text { Temporal characteristics: } \\
\text { Year of publication } \\
\text { Mid point of observation period } \\
\text { Initial year of the sample } \\
\text { End of period the sample } \\
\text { Time frequency data (monthly) } \\
\text { Time frequency data (quarterly) } \\
\text { Dummy in decade : } \\
\text { Dummy for the 1960's data used in the study } \\
\text { Dummy for the 1970's data used in the study } \\
\text { Dummy for the 1980's data used in the study } \\
\text { Dummy for the 1990's data used in the study } \\
\text { Length of observation period in the study (in quarters) } \\
\text { Length of time-lag used in the sample (in quarters) }\end{array}$ & $\begin{array}{l}185 \\
185 \\
185 \\
185 \\
185 \\
185\end{array}$ & $\begin{array}{c}0.3459 \\
0.2595 \\
0.3946 \\
79.51351 \\
19.0649 \\
1.9189 \\
\\
2000.838 \\
1983.792 \\
1972.4760 \\
1995.1080 \\
0.1568 \\
0.8432\end{array}$ & $\begin{array}{c}0.4302 \\
0.4090 \\
\\
0.4943 \\
\\
0.4770 \\
0.4395 \\
0.4901 \\
30.60497 \\
17.2912 \\
0.8962 \\
\\
2.634569 \\
8.543443 \\
12.5326 \\
6.3348 \\
0.3646 \\
0.3646 \\
\\
0.2040 \\
0.4733 \\
0.4533 \\
0.4733 \\
37.7718 \\
0.9167\end{array}$ & $\begin{array}{c}0.0000 \\
0.0000 \\
\\
0.0000 \\
\\
0.0000 \\
0.0000 \\
0.0000 \\
32 \\
3.0000 \\
1.0000 \\
\\
1995 \\
1969 \\
1958 \\
1978 \\
0.0000 \\
0.0000 \\
\\
0.0000 \\
0.0000 \\
0.0000 \\
0.0000 \\
42.0000 \\
1.0000\end{array}$ & $\begin{array}{c}1.0000 \\
1.0000 \\
\\
1.0000 \\
1.0000 \\
1.0000 \\
1.0000 \\
207 \\
48.0000 \\
4.0000 \\
\\
2007 \\
2001 \\
1998 \\
2004 \\
1.0000 \\
1.0000 \\
\\
1.0000 \\
1.0000 \\
1.0000 \\
1.0000 \\
228.0000 \\
5.0000\end{array}$ \\
\hline 3. & $\begin{array}{l}\text { Conditioning variables } \\
\text { Capital intensity measure (total shares of manufacturing } \\
\text { and construction sectors to GDP) } \\
\text { Share of manufacturing sector (\% of GDP) } \\
\text { Share of construction sector (\% of GDP) } \\
\text { Economic size (GDP in US dollars) in Log. } \\
\text { Percents of export to GDP } \\
\text { Share of bank-credits disbursed to private institutions (\% to GDP) } \\
\text { Number of bank-offices per } 100.000 \text { people (in log) } \\
\text { Stock market capitalization (\% of GDP) } \\
\text { Dummy for floating exchange rate regime } \\
\text { Dummy for pegged exchange rate regime } \\
\text { Population size or number of people (in log) } \\
\text { Geographical and temporal characteristics: } \\
\text { Country-level dummy } \\
\text { Regional-level dummy } \\
\text { USA dummy } \\
\text { Eurozone (EMU) dummy } \\
\text { European union (non-eurozone) dummy }\end{array}$ & $\begin{array}{l}185 \\
185 \\
185 \\
185 \\
185 \\
185 \\
185 \\
185 \\
185 \\
185 \\
185\end{array}$ & $\begin{array}{c}35.3547 \\
28.0749 \\
7.2798 \\
18.8570 \\
24.0872 \\
57.4745 \\
34.5494 \\
50.2907 \\
0.5351 \\
0.4649 \\
16.2485\end{array}$ & $\begin{array}{c}10.8232 \\
8.7990 \\
4.4852 \\
1.3665 \\
19.0209 \\
31.2479 \\
16.9597 \\
29.1044 \\
0.5001 \\
0.5001 \\
1.3434 \\
\\
0.4968 \\
0.4968 \\
0.4968 \\
0.4912 \\
0.3745\end{array}$ & $\begin{array}{c}9.6600 \\
3.6000 \\
3.4800 \\
15.6338 \\
6.5700 \\
15.2500 \\
2.1890 \\
2.8200 \\
0.0000 \\
0.0000 \\
12.8064\end{array}$ & $\begin{array}{c}60.2660 \\
39.8900 \\
30.1330 \\
21.4003 \\
74.1700 \\
120.2400 \\
95.9000 \\
129.5400 \\
1.0000 \\
1.0000 \\
18.2228\end{array}$ \\
\hline
\end{tabular}


halaman ini sengaja dikosongkan 